\title{
p53 as the main traffic controller of the cell signaling network
}

\section{Sinto Sebastian ${ }^{1}$, Amalia Azzariti ${ }^{1}$, Nicola Silvestris ${ }^{2}$, Letizia Porcelli ${ }^{1}$, Antonio Russo ${ }^{3}$ Massimo Tommasino ${ }^{4}$ and Angelo Paradiso ${ }^{1}$}

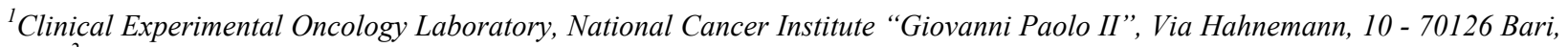
Italy, ${ }^{2}$ Medical and Experimental Oncology Unit, National Cancer Institute "Giovanni Paolo II", Via Hahnemann, 10 - 70126 Bari, Italy, ${ }^{3}$ Section of Medical Oncology, Department of Surgery and Oncology, University of Palermo, Palermo, Italy, Infections and Cancer Biology Group, International Agency for Research on Cancer, 150 Cours Albert Thomas, 69372 Lyon Cedex 08, France

\section{TABLE OF CONTENTS}

\author{
1. Abstract \\ 2. Introduction \\ 3. Unexpected roles of 553 as a major traffic controller \\ 4. p53 as traffic controller: modes of activation and signaling mechanism \\ 4.1. DNA damage \\ 4.2. Oncogene activation \\ 4.3. Hypoxia \\ 4.4. Microtubule disruption \\ 4.5. Replicative senescence \\ 5. The elegant model of $p 53$ regulation \\ 6. p53 ability to switch on and off genes \\ 7. Events downstream of the $p 53$ activation \\ 7.1. Growth arrest \\ 7.2. DNA repair \\ 7.3. Apoptosis \\ 7.3.1. p53 role in transcription dependent apoptosis \\ 7.3.2. Role of p53 in transcription independent apoptosis \\ 8. Dysfunction of p53 traffic controller in human cancer \\ 8.1. Polymorphisms in TP53 \\ 8.2. Mutations in TP53 \\ 8.3. Virus infections \\ 8.4. p53 family isoforms \\ 9. Concluding notes \\ 10. References
}

\section{ABSTRACT}

Among different pathological conditions that affect human beings, cancer has received a great deal of attention primarily because it leads to significant morbidity and mortality. This is essetnially due to increasing worldwide incidence of this disease and the inability to discover the cause and molecular mechanisms by which normal human cells acquire the characteristics that define cancer cells. Since the discovery of p53 over a quarter of a century ago, it is now recognized that virtually all cell fate pathways of live cells and the decision to die are under the control of p53. Such extensive involvement indicates that p53 protein is acting as a major traffic controller in the cell signaling network. In cancer cells, many cell signaling pathways of normal human cells are rerouted towards immortalization and this is accomplished by the corruption of the main controllers of cell signaling pathways such as p53. This review highlights how p53 signaling activity is altered in cancer cells so that cells acquire the hallmarks of cancer including deregulated infinite self replicative potential.

\section{INTRODUCTION}

In the dynamic development of multi-cellular organisms including humans, certain proteins act as coordinators and/or major traffic controllers of different cellular networks. p53 and the p53 family network are thought to be the primary players of the cell signaling pathway that control both internal and external signals received by cells. p53, $(53 \mathrm{Kd})$, also known as tumor protein 53 (TP53), was first identified in 1979 as a cellular protein that bound large $\mathrm{T}$ antigen to the simian virus (SV40) and accumulated in cancer cell nuclei (1). The gene encoding p53 (TP53) was cloned from rodent and human neoplastic cells, and found to have weak oncogenic activity when expressed in rodent cells. However, in the late 1980s, it was discovered that, instead of the wild-type gene, the form of $\mathrm{p} 53$ that was studied had missense mutilation. The missense mutations found in the original TP53 cDNA clones proved to be the key to understanding the pathobiological activity of p53 (2). The ability of p53 to form tetramers allows this protein to behave in a dominantnegative fashion in which the allele-producing mutant p53 


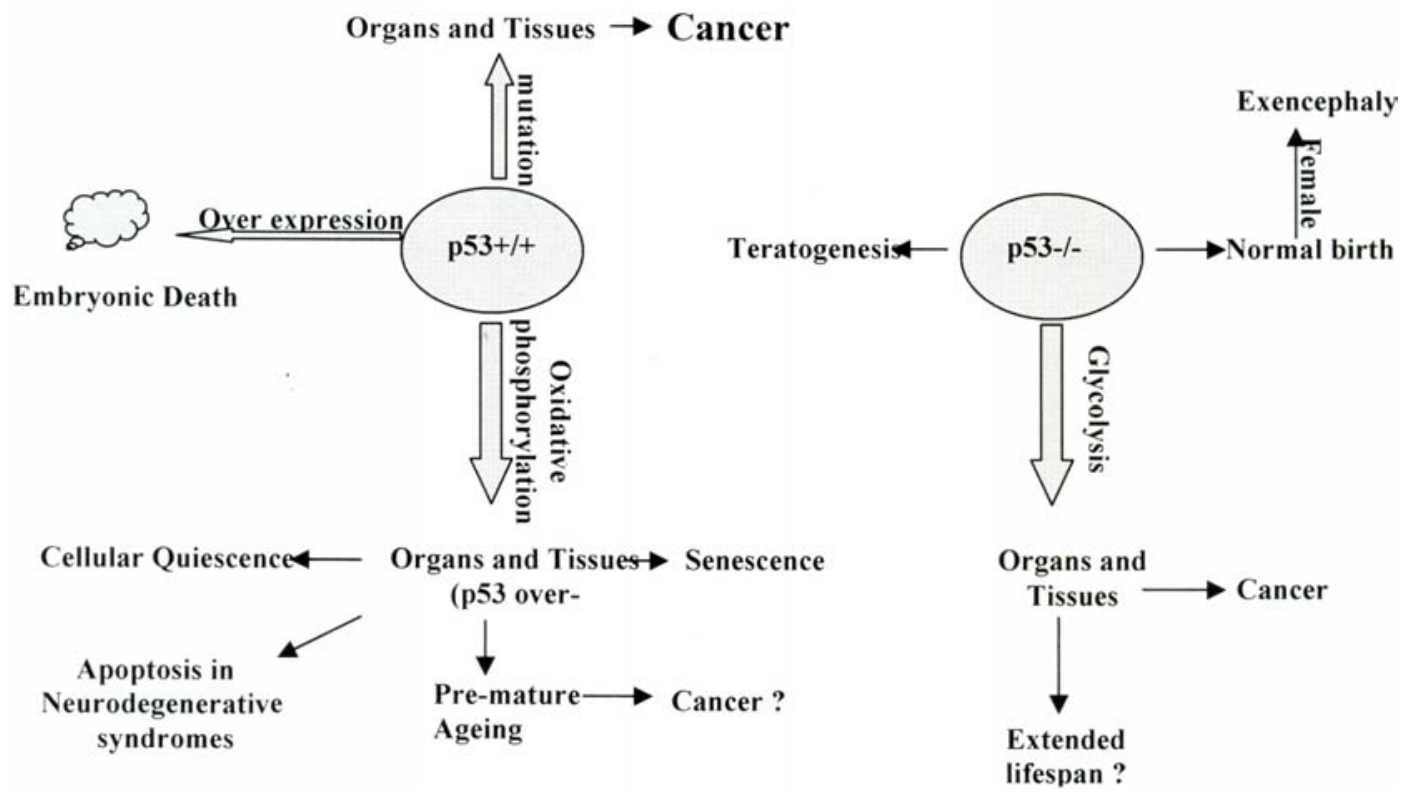

Figure 1. p53 function as a major traffic controller of cell signaling pathways from cellular origin to death: Schematic representation of possible cell fate determination pathways that can be activated and/or repressed by p53 wild type protein.

suppresses the activity of wild-type p53. The ability of p53 to act as a tumor suppressor transcription factor was finally revealed in 1989 by Bert Vogelstein (3). p53 is considered to be a tumor suppressor due to its ability to induce cell cycle inhibition and/or apoptosis. Most cancers acquire inactive p53 (mainly by mutation) and introduction of p53 to these cells induces apoptosis and/or senescence. Many mechanisms mask tumor suppressor functions of wild-type p53. Abundance of p53 and numerous posttranslational modifications most notably, phosphorylation and acetylation, modulate p53 activity (4). p53 protein function is also regulated by expression of other members of the p53 family, such as p63 and p73, which specifically depends on: a) the balance between the expression of transcriptionally active (p53, TAp63, and TAp73) and inactive isoforms (DNp63, DNp53 and DNp73); b) their interaction and competition at DNA-responsive elements; c) their interaction with regulatory, both inhibitory and activating, proteins $(5,6)$. In non-stressed cells, p53 is essentially kept inactive through the actions of the ubiquitin ligase MDM2, which inhibits transcriptional activity of p53 and ubiquitinates p53 leading to its degradation. p53 is considered to be "the guardian of the genome," "the guardian angel gene," and the "master watchman," mainly due to its role in preventing genome mutation. In this paper, also the recent emerging role of p53 as major traffic controller of cell signalling pathway are reviewed. Understanding the molecular mechanisms responsible for each p53 opens the possibility to develop better therapeutic strategies.

\section{UNEXPECTED ROLES OF P53 AS A MAJOR TRAFFIC CONTROLLER}

p53 protein has been intensively studied mainly as a tumor suppressor in humans and other mammals (7). Loss or mutation of p53 is strongly associated with increased susceptibility to cancer, and most functions of p53 have been considered in the light of use of p53 to prevent malignant progression (8). Since some p53-null mice were able to develop normally (9), it was originally thought that p53 did not have any major function in normal physiology, a view that had recently been changed. p53 is involved in regulating longevity and aging, glycolytic pathways that might determine endurance and overall fitness, and in apoptotic responses during ischemic and other types of stress. Evidence for genetic variations in the activity of the p53 pathway in humans makes these ideas as being more relevant (10). As a transcription factor, p53 is a major mechanism that both positively and negatively regulates the expression of a large and disparate group of responsive genes (11). Numerous studies, including the recently reported genome wide ChIP analyses (12-13), have identified p53-regulated genes that may play a role in a number of different and sometimes unexpected responses. Although some of these functions still need to be fully validated, there is now clear evidence that p53 plays a role in the regulation of glycolysis (14-15) and autophagy (16), the repair of genotoxic damage (17), cell survival, regulation of oxidative stress (18), invasion and motility (19), cellular senescence (20), angiogenesis (21), differentiation (22), and bone remodeling (23) (Figure 1). Such extensive involement of p53 in cell functions, therefore, suggests that in addition to the role of p53 as a "guardian of the genome", p53 acts as a main traffic controller in the cell signaling network.

\section{P53 AS TRAFFIC CONTROLLER: MODES OF ACTIVATION AND SIGNALING MECHANISM}

Efficient control of p53 is critical in normal cell growth. A number of mechanisms that lead to the stabilization and activation of p53 have been identified that 


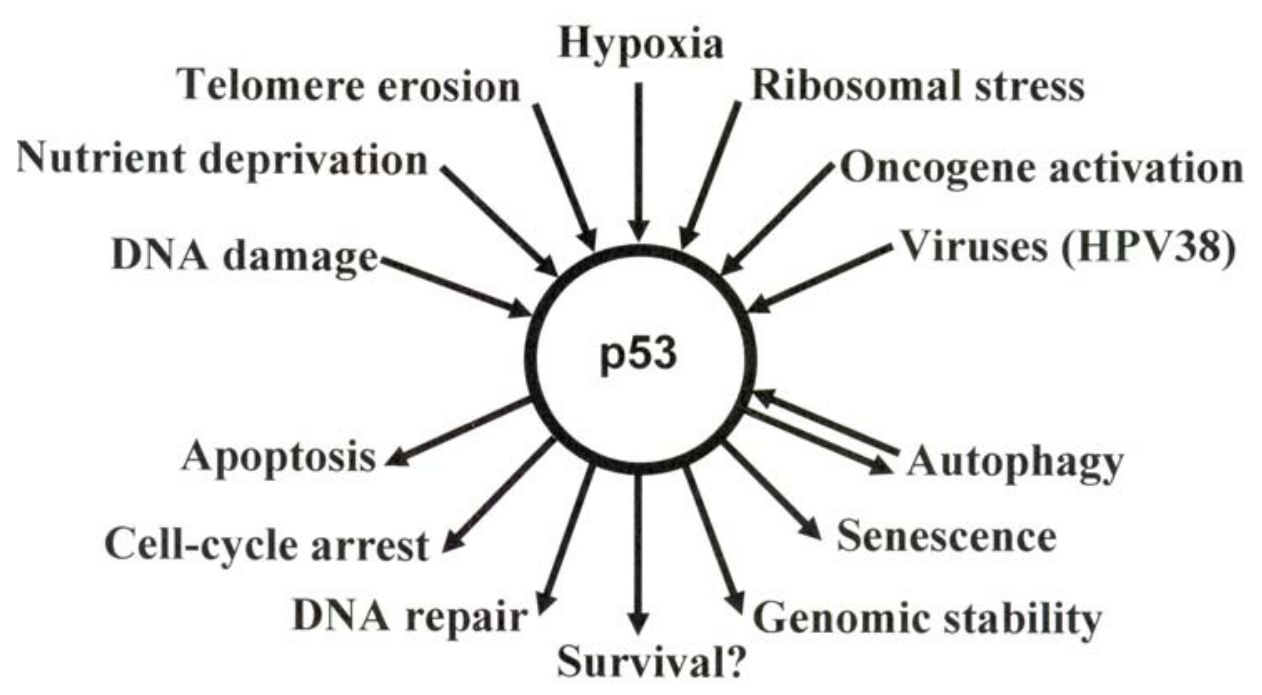

Figure 2. Duties of p53 traffic controller. p53 has a key role in integrating the cellular responses (arrows pointing out from p53) to different types of stress (arrows pointing towards p53). Activation of p53 can result in a number of cellular responses and it is possible that different responses are induced by different stress signals. There is evidence that p53 can play a part in determining which response is induced through differential activation of target-gene expression. Although the importance of these responses to tumour suppression is clear, previously unanticipated contributions of these responses to other aspects of human health and disease are being uncovered. The role of p53 in tumour suppression, development and ageing depends on which cellular response is activated and on the context in which the activation occurs.

participate in such a control. Release of the tight control over p53 with activation of p53 is a well-established response to stress (Figure 2). Analysis of the p53 orthologue in flies and worms shows that, as seen in mammalian systems, p53 is an integral component of the response to genotoxic stress (24-26). p53 is extremely sensitive to low levels of DNA damage, a response that is thought to contribute to tumor suppression by either promoting repair or by eliminating cells harboring potentially oncogenic alterations. However, many other signals can also activate $\mathrm{p} 53$, including inappropriate cell proliferation driven by oncogene activation, telomere erosion, DNA damage, nutrient deprivation and hypoxia (27). Importantly, these signals do not all engage p53 through the same pathways, but use different signaling molecules to stabilize and activate p53. For example, ARF, a small protein that binds and inhibits MDM2, has an important role in signaling to p53 in response to some oncogenes, but it is not necessary for the activation of $\mathrm{p} 53$ in response to DNA damage (28-29). Similarly, without a requirement for $\mathrm{ARF}$, the ribosomal protein, $\mathrm{L} 11$, has a role in activating p53 in response to ribosomal stress (30). Although a response to genotoxic stress certainly seems to be the most historic function of p53 in evolutionary terms, a recent study using a mouse model in which p53 can be switched on and off has indicated that the response of p53 to DNA damage might not be responsible for tumor suppression (31). This study shows that p53 becomes important only after the bulk of the damage has been resolved, and concludes that the key tumor-suppressor function of p53 is to respond to oncogene activation that occurs as a consequence of the original genotoxic stress. In support of this idea, there are studies showing that ARF, which is necessary for oncogene-induced (but not DNA- damage-induced) activation of $\mathrm{p} 53$, is responsible for almost all the tumor-suppressor activity of p53 (32). Thus, it appears that different signals use different pathways to activate $\mathrm{p} 53$, leading to the interesting question whether all of these pathways are equally important for the inhibition of tumor development.

\subsection{DNA damage}

Warren Maltzman demonstrated that TP53 was responsive to DNA damage caused by ultraviolet radiation (33). DNA damage was the first type of stress found to activate p53 and based on this finding, p53 is widely regarded as "the guardian of the genome" (34). In the extensive characterization of the signaling routes that connect DNA damage with p53, a cascade of Ser/Thr kinases, which includes ATM, ATR, Chk1 and Chk2, has been identified that all lead to phosphorylation of p53 (3538). This signaling cascade may be permanently activated in some cancers, suggesting that the cancerous state might be intrinsically associated with the generation of DNA damage (39-40). The constitutive DNA damage in cancer cells is thought to originate primarily from strong generation of reactive oxygen species (ROS) (41) as well as from aberrant firing of DNA replication origins (42-43). Recent characterization of mice, genetically manipulated with a knocked-in p53 that cannot be phosphorylated at two of the main residues targeted by ATM/ATR/Chk1/Chk2, namely, Ser18 and Ser23 (Ser15 and Ser20 in human p53), indicates an important role of these phosphorylation sites in some, but not all, DNA damage induced and p53-dependent responses (44). In agreement with this, mice carrying $\mathrm{p} 53 \mathrm{~S} 18 \mathrm{~A} / \mathrm{S} 23 \mathrm{~A}$ alleles are tumor prone (44) although this phenotype is considerably milder than in the case of p53null mice (45-46). These data suggest that the activation of 
$\mathrm{p} 53$, in response to DNA damage, occurs through multiple pathways, which in addition to the well-established kinase cascade of ATM/ATR/Chk1/Chk2, probably includes other kinases such as p38, JNK/SAPK, and c-Abl (47-52). Regarding human cancer, the available information gathered from the analysis of (epi)genetic aberrations indicates that the DNA damage signaling kinases are not, in general, significant targets of genetic and epi-genetic inactivation (53-55). The only exception to this is found in hematological malignancies, which present a high incidence of mutations in ATM (13-40\% depending on the particular type of malignancy) (56). In agreement with this, a recent large-scale sequencing effort of 210 diverse human cancers has identified ATM as one of the three most frequently mutated kinases (5\% incidence) (57). Based on such genetic evidence, it can be concluded that DNA damage is conveyed to p53 through multiple redundant pathways. Many transducers participate in such a response but none of these plays a critical role and for this reason, alteration of a single component may have relatively minimal impact on $\mathrm{p} 53$ function.

\subsection{Oncogene activation}

Among the many and varied stimuli that have been reported to activate $\mathrm{p} 53$, oncogenic signaling (58) has received a great deal of attention because, similar to the DNA damage, alteration of such signaling pathways is universally found in cancer. It is for this reason that a function as a traffic controller of oncogenes can be assigned to $\mathrm{p} 53$. When activated or over-expressed oncogenes such as Ras, c-Myc, or E1a stabilize and activate $\mathrm{p} 53$, and depending on the cell type, induce senescence (Ras) or apoptosis (c-Myc or E1a) through hyperproliferative signaling pathways that activate ARF, the product of the alternative reading frame of the cellcycle regulatory gene INK4a/CDKN2a (59). Oncogenic signaling activates p53 through ARF, (60-62) which, in turn, interacts with MDM2 inhibiting its p53-ubiquitin ligase activity. Consequently, ARF-dependent stabilization of $\mathrm{p} 53$ results in a dramatic increase in p53 activity. Many transcription factors activate ARF in response to oncogenic signaling (63-64), most notably DMP1 (Dentin matrix acidic phosphoprotein-1) (65-66). Mice lacking ARF have a remarkable tumor-prone phenotype (67-68) although this is not as severe as p53-deficient mice, (45-46) and there is good genetic evidence in mice supporting the relevance of the ARF/MDM2/p53 axis in tumor suppression (29). Importantly, ARF-deficient-mice present a normal DNA damage response, indistinguishable from ARF-proficient mice (28). Regarding human cancer, the analysis of (epi)genetic alterations indicate that $\mathrm{ARF}$ is indeed inactivated at an extraordinary high frequency $(\sim 30 \%)$ in cancer (63). However, inactivation of ARF almost invariably occurs in combination with the loss the cell cycle inhibitor, p16INK4a, leading to the uncertainty as what exactly is the key targeted tumor suppressor. It should be mentioned, in this regard, that germline point mutations that inactivate ARF alone (i.e. sparing p16INK4a) exist in human kindreds predisposed to cancer (69-70). Nevertheless, the number of germline mutations that inactivate only p16INK4a (i.e. sparing ARF) outnumbers those that inactivate ARF alone by a factor of 20 (71). The currently available evidence indicates that ARF is an important upstream regulator of $\mathrm{p} 53$, whose lack of activity has a significant impact on cancer. Based on the observation that Ser15 in p53 was not phosphorylated in response to adenovirus E1A expression, it was concluded that oncogenic activation of p53 occurs in the absence of DNA damage (71). However, brief c-Myc overexpression in normal fibroblasts induced DNA damage signals which correlated with induction of ROS (72), raising the question as whether or not oncogenes activate p53 through DNA damage and whether the ability of oncogenes to promote apoptosis or senescence correlates with different posttranslational modifications of p53. Ferbeyre et al (73) reported that expression of oncogenic Ras in IMR90 cells induced phosphorylation of $\mathrm{p} 53$ at Ser15. In contrast, Bulavin et al (74) found p53 was phosphorylated at Ser33 and Ser46 but not at other N- or C-terminal sites, nor was it acetylated at Lys382. Interestingly, a similar induction of permanent cell cycle arrest resembling cellular senescence was produced in murine fibroblasts engineered to express the MAP kinase Mek1 (73). The induction of senescence by Ras required wild-type p53 and ARF, but p53 was not required to maintain the senescent state. These data indicate that other signals may influence the outcome of p53 activation, which probably occurs through the association of p53 with various coactivators. However, whether or not this leads to the expression of different p53 target genes remains to be determined. Based on such understanding, p53 is now known as "the traffic controller" of cell signaling pathway.

\subsection{Hypoxia}

Cells that reside at a distance of $150 \mathrm{~m}$ or more from blood supply in tumors often experience hypoxia, a condition that is common in most solid tumors because of the abnormal development of vasculature. Hypoxia is also an important pathophysiological feature of ischemic disorders. Hypoxia and several hypoxia mimetics have been shown to induce accumulation of p53 as a result of the down-regulation of MDM2 (75) with concomitant phosphorylation of Ser15 but not acetylation of Lys382 (76). However, in contrast to Ionizing radiation (IR), hypoxia treatment fails to induce the transcription of downstream effectors, GADD45, Bax, and p21 (76). Hypoxia does not induce detectable DNA damage, and in contrast to DNA damage-inducing agents, hypoxia primarily causes an association of $\mathrm{p} 53$ with $\mathrm{mSin} 3 \mathrm{~A}$ rather than p300. Consistent with this finding, p53-mediated transrepression was induced. In hypoxia treated human papillomavirus HPV-16 transformed cells, p53 was resistant to E6-mediated degradation, and its association with E6AP was reduced (75). Interestingly, a recent study has shown that inhibition of ATR kinase activity reduced the hypoxia-induced phosphorylation of $\mathrm{p} 53$ protein on Ser15 as well as accumulation of p53 protein (77). This data suggests that hypoxia can become selective because of the loss of ATR-dependent checkpoint controls, thus promoting cell transformation.

\subsection{Microtubule disruption}

Activation of p53 occurs in response to such factors as colcemid, nocodazole, and taxol that deregulate 


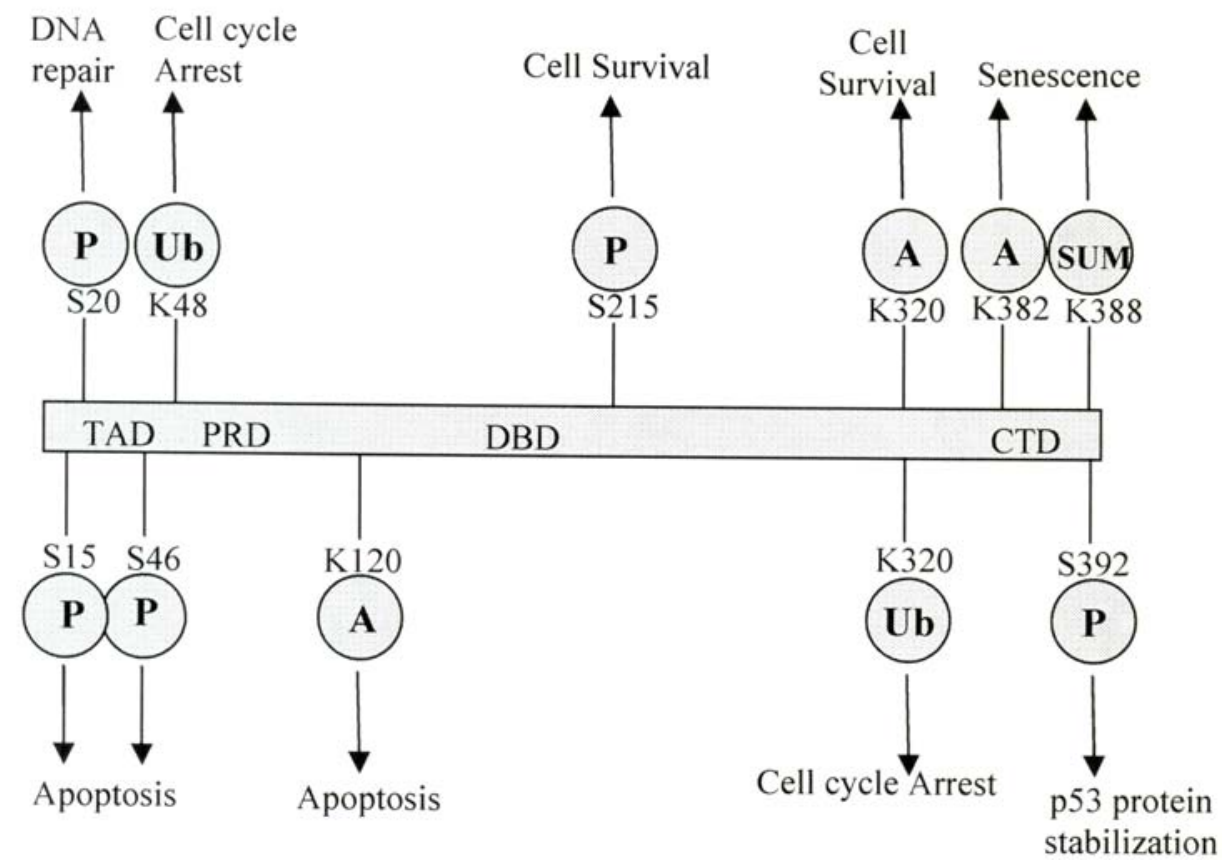

Figure 3. Signals of activated p53 traffic controller for different cell fate determination. Specific residues are modified as shown, with phosphorylation (p), acetylation (A), ubiquitination (Ub), Sumoylation (SUM). Different cell fate determinations after these modifications are shown in matching. TAD, Transactivation domain; PRD, prolin-rich domain; DBD, DNA-binding domain; CTD, C-terminal regulatory domain

cell adhesion or architecture and dynamics of microtubule. Taxol (Paclitaxel), which inhibits microtubule depolymerization, is one of the chemotherapeutic drugs, commonly used in treating ovarian, breast, head and neck cancers. After nocodazole treatment, which depolymerizes microtubules, quiescent human fibroblasts accumulated transcriptionally active $\mathrm{p} 53$ and arrested in $\mathrm{G}_{1}$ with a $4 \mathrm{~N}$ DNA content (78). Activation of p53 after colcemid treatment was accompanied by a moderate increase in phosphorylation at Ser15 and correlated with activation of Erk1/2 MAP kinases and the development of focal adhesions rather than disruption of the microtubule system (79). Curiously, murine fibroblasts did not undergo the same response. Taxol and vincristine, but not nocodazole, were found to induced multi-site phosphorylation of p53 in several tumor-derived human cell lines, including HCT-116 and RKO cells, and the pattern of p53 phosphorylation was distinct from that observed after DNA damage (80). Nevertheless, both nocodozole and taxol increased phosphorylation at Ser15. Interestingly, microtubule inhibitor-induced p53 stabilization and Ser15 phosphorylation did not occur in ATM-deficient fibroblasts nor in normal human dermal fibroblasts. Studies with ectopically expressed p53 phosphorylation site mutants indicated that several p53 amino-terminal residues, including Ser15 and Thr18, were required for the taxolmediated phosphorylation of p53 (80). In contrast, Damia et al (81) reported taxol induced p53 phosphorylation in HCT-116 cells at Ser20 but not at Ser15. Phosphorylation at Ser20 was accompanied by increased Chk2 activity and was not inhibited in A-T cell lines or by wortmannin treatment. Therefore, the signaling pathways that impinge on p53 after hypoxia and microtubule disruption are distinct from those induced by genotoxic stresses.

\subsection{Replicative senescence}

Replicative senescence in human fibroblasts correlates with activation of p53-dependent transcription and was shown to be associated with increased phosphorylation at Ser15, Thr18, and probably at Ser376, and with decreased phosphorylation at Ser392 (82). Since staining with the DO-1 monoclonal antibody, which detects phosphorylation at Ser20 failed to show positive staining, it was inferred that phosphorylation on Ser20 was not inducible upn senescence. These results together with findings showing that changes in $\mathrm{p} 53$ phosphorylation are abrogated in cells immortalized by overexpression of telomerase indicate that these modifications may result from telomere erosion. Shortened or disrupted telomere structures may signal to p53 via pathways that are partially shared with DNA damage responses.

\section{THE ELEGANT MODEL OF P53 REGULATION}

The post-translational modifications that can positively or negatively regulate cell fate determination and tumorigenic role of $\mathrm{p} 53$ protein as a tumor suppressor has been studied in great detail (Figure 3). As partially described in Section 3 , human $\mathrm{p} 53$ has 23 different phosphorylation and dephosphorylation sites. Regulation of p53 function by phosphorylation and dephosphorylation occurs at many sites, most of which reside outside the DNA binding domain (DBD). Most residues are phosphorylated by many different kinases in response to many different 
Table 1. p53 mediated transcriptionaly repressed and activated genes

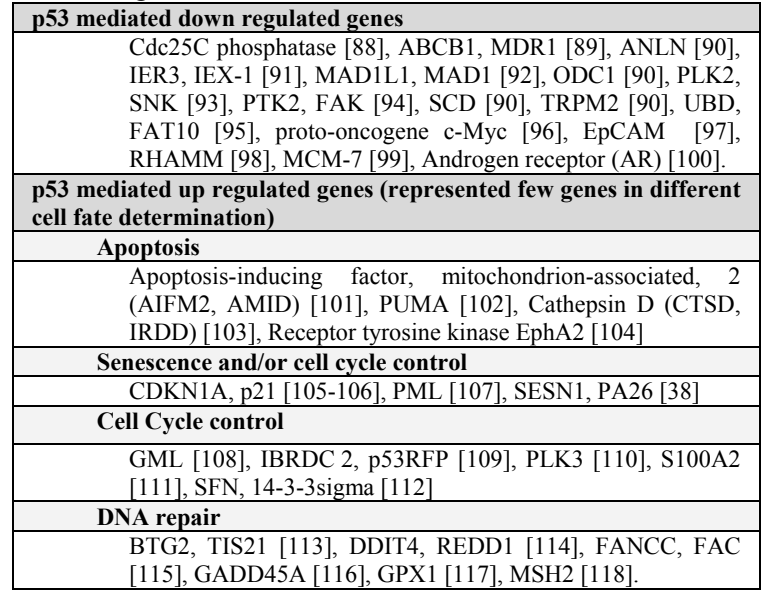

p53 has been reported to act as repressor and activator of different cell fate determining genes. In this table major genes repressed by p53 transcription factor and activated in different cell functions has been summarized

stresses and are associated with p53 activation (83). This defines two levels of potential redundancy: first, a specific residue can be phosphorylated by several different kinases (for example, serine 15 is phosphorylated by at least 8 kinases), and second the same kinase can phosphorylate p53 at several residues (for example, CHK2 phosphorylates 7 different residues). Such redundancy might provide a failsafe mechanism to enable different stresses to activate p53 (83). As some residues seem to be phosphorylated by a single kinase, a unique phosphorylation pattern might determine a subset of cellular responses. Alternatively, this could reflect our incomplete knowledge of relevant kinases and their targets. For example, Ser378 was thought to be phosphorylated by a single kinase just 2 years ago (83), but recent data indicate that three different kinases are involved (84). Furthermore, the dephosphorylation of some residues has been correlated with activation. Therefore, Ser376 is phosphorylated in unstressed cells and dephosphorylated after ionizing irradiation, correlating with the interaction of p53 with 14-3-3 proteins (85). C-terminal lysines of p53 are modified by ubiquitination, acetylation, sumoylation, neddylation, and methylation. Neddylation seems to inhibit transactivation, whereas sumoylation positively or negatively affects p53 function (83). It has recently been suggested that p53 sumoylation induces senescence in normal human fibroblasts but apoptosis in RB (retinoblastoma 1)-deficient cells (86). Rather than apoptosis, it was suggested that modifications to Lys320 promote cell-cycle arrest (87-89). In contrast to Lys372, 373,381 , and 382 , which are all acetylated by p300 and ubiquitylated by MDM2 (83), Lys320 is acetylated by the p300 and CBP associated factor (PCAF) $(87-88,90)$ and ubiquitylated by E4F1 (89). Methylation at nearby lysines may also have dramatically different effects: Lys 372 methylation by SET9 stabilizes p53 (91), whereas the methylation of Lys370 by SMYD2 destabilizes it. The increasing variety and complexity of p53 modifications at serines, threonines and lysines shows elegant models involved in $\mathrm{p} 53$ regulation.

\section{P53 ABILITY TO SWITCH ON AND OFF GENES}

The most studied and characterized mode of action of p53 is its function as a transcription factor. The role of modifications and cofactors, which ensure its presence in the nucleus, is just one aspect of the signboard in a signaling network. However, the possibility that p53 switches a particular gene expression on or off (Table 1) is determined by its post-translational modifications, the action of cofactors, or a combination of both of these two mechanisms. Modifications of specific residues in p53 can also directly influence the promoter to which p53 will bind. In response to UV and genotoxic stress, p53 is respectively phosphorylated on Ser46 by the kinases homeodomaininteracting protein kinase-2 (HIPK2) and the dualspecificity tyrosine-phosphorylation-regulated kinase-2 (DYRK2) (119-121). This occurs in the later stages of p53 activation and influences the response by specifically promoting the induction of the apoptotic genes p53AIP1, PUMA, Noxa, and PTEN (122-125). This is accompanied by down regulation of $\mathrm{p} 21$ expression, ultimately resulting in p53-dependent apoptosis. Furthermore, p53-dependent apoptosis can be specifically enhanced following DNA damage through the acetylation of Lys120 by the MYST family acetyltransferases MoF and TIP60. Lys120 lies in the DNA-binding domain of $\mathrm{p} 53$, and its acetylation leads to increased specific recruitment of p53 to pro-apoptotic target genes such as Puma and Bax, suggesting that this modification alone can influence how p53 responds to DNA-damage signals (Figure 3). This modification appears to be required for p53-dependent apoptosis i.e. mutants that can no longer be modified in this way, exhibit impaired apoptotic activity while maintaining the proper regulation of Mdm2 and cell-cycle-arrest genes (126-127). These data show that a defined p53 modification can be linked to a specific cellular outcome. In contrast, Lys320 of p53 can be modified independently by both acetylation and Ubiquitination to influence promoter selectivity. The e3 ligase, e4F1, ubiquitinates p53 at Lys320, and specifically increases the activation of cell-cycle-arrest genes, such as p21, Gadd45, and cyclin G1 while the expression of apoptotic targets remains unchanged (89). Chromatin immunoprecipitation experiments demonstrated that Lys320-ubiquitinated p53 was bound to the p21 gene promoter but not to that of the apoptotic target gene, Noxa. Similarly, acetylation of Lys320 following drug-induced DNA-damage promotes cell survival, with Lys320acetylated $\mathrm{p} 53$ binding more efficiently to the $\mathrm{p} 21$ promoter than to the non-acetylated form of p53 (88). Despite their apparent overlapping functions, the modification of Lys 320 by these two distinct mechanisms appears to be mutually exclusive as ubiquitination abolishes acetylation, and vice versa (89). Thus, the two modifications may represent a way that p53 can selectively target cell-cycle arrest genes in response to different incoming signals. Furthermore, the same modification on the same residue can also result in different cellular outcomes. Acetylation of Lys320 in neuronal cells does not cause cell-cycle arrest, but it is specifically involved in promoting neurite outgrowth by elevating the expression of two p53 target genes: firstly, coronin $1 \mathrm{~b}$, which encodes an actin-binding protein, and secondly Rab13, which encodes a GTPase (128). Thus, 
even the same modification can cause markedly different outcomes depending on the tissue in which activation occurs. Ultimately, these differences must be due to the presence of cofactors in the cell that are differentially expressed from one cell type to another. Therefore, analysis of p53 cofactors must be taken into consideration when attempting to predict the $\mathrm{p} 53$ response.

\section{EVENTS DOWNSTREAM FROM P53} ACTIVATION

Once the p53 protein is activated, it initiates a transcriptional program that reflects the nature of the stress signal, protein modifications, and of the proteins associated with the $\mathrm{p} 53$ protein. The $\mathrm{p} 53$ protein binds to a specific DNA sequence, termed the p53-responsive element (RE) (129-130) and induces the expression of downstream genes. The genes in this p53 network mainly initiate one of three programs that result in cell cycle arrest, DNA repair or apoptosis.

\subsection{Growth arrest}

p21WAF1/CIP1 is known to be a p53downstream gene, and has been suggested to mediate p53induced growth arrest triggered by DNA damage. The p21 protein is a cycline-dependent kinase inhibitor that associates with a class of CDKs and inhibits their kinase activities. This will facilitate the accumulation of the hypophosphorylated form of $\mathrm{pRB}$ that in turn associates with E2F, inhibiting its transcriptional activity and leading to cell cycle arrest. As long as $\mathrm{pRb}$ is bound to $\mathrm{E} 2 \mathrm{~F}$, the cell is prevented from entering into $\mathrm{S}$ phase. This $\mathrm{G} 1$ arrest provides the cell the opportunity to repair DNA damage. Thus, if the repair is successful, p53 level drops and CDKcyclin protein kinase activity resumes, leading to entry into $\mathrm{S}$ phase. If DNA is not repaired, p53 triggers apoptosis (131-132). As a block occurs in G2 phase, there is recent evidence that p53 can control entry into mitosis in the presence of damaged DNA or in S phase due to depletion of the substrates required for DNA synthesis. Part of the mechanism by which p53 blocks cells at the G2 checkpoint involves inhibition of $\mathrm{Cdc} 2$, the cyclin dependent kinase required to enter mitosis (133). Cdc2 is simultaneously inhibited by three transcriptional targets of $\mathrm{p} 53$, Gadd45, p21, and by $14-3-3 \sigma$ (134). Binding of Cdc2 to Cyclin B1 is required for its activity, and repression of the cyclin B1 gene by $\mathrm{p} 53$ also represses the cdc 2 gene thereby helping to ensure that cells do not escape the initial block (135).

\subsection{DNA repair}

Soon after TP53 was established in the 1990s as the most frequently altered gene in human tumors (136137), it was found that $\mathrm{p} 53$ is a major component of the DNA damage response pathway $(34,138)$. Once DNA injuries occur, the level of $\mathrm{p} 53$ protein rises, which in turn induces a transient cell cycle arrest or apoptotic cell death. The p53 protein senses DNA damage and can halt progression of the cell cycle in $G_{1}$ as a result of posttranslational modifications caused by specific kinases such as the strand break sensor, ataxia telangiectasia mutated protein (Atm), acetyltransferases like CREB-binding protein $(\mathrm{Cbp}) / \mathrm{p} 300$, and the poly (ADPribose) polymerase
1 (Parp-1), which prevent proteolysis via the Arf-mouse double minute $2(\mathrm{Mdm} 2)$ pathway and/or enhance binding of p53 to consensus sequences within the genome (139141). The C-terminal 30 amino acids of $\mathrm{p} 53$ were shown to recognize several DNA damage-related structures such as DNA ends, gaps, and insertion/deletion mismatches (142145). p53 was also demonstrated to catalyze reannealing of short stretches of single- and double-stranded DNA and to promote strand exchange between them (142, 146-147). Furthermore, p53 binds to three-stranded heteroduplex joints and four-stranded Holliday junction DNA structures, specifically localized at the junction, suggesting that p53 directly participates in recombination repair (148-150). Moreover, several research groups demonstrated $\mathrm{Mg}^{2+}$ dependent 3' -5 ' exonuclease activity intrinsic to p53 (138, 151). In addition to p53 biochemical activities, numerous reports on physical and functional protein interactions further strengthened the suggestion that p53 plays a direct role in nucleotide excision repair (NER), base excision repair (BER), and double-strand break (DSB) repair (152154). However, it must be emphasized that p53 is not the only potential gene directly involved in DNA repair as other genes are also involved.

\subsection{Apoptosis}

Pivotal to the tumor-suppressor activity of p53 is its ability to activate apoptosis via multiple pathways (155). However, although a large number of genes, regulated by p53 during induction of apoptosis, are known (155), no single target gene has been identified whose altered expression alone is sufficient to explain p53 mediated transcription dependent apoptosis, and whose genetic deficiency phenocopies p53 deficiency in vivo. As an additional mode of p53 pro-apoptotic activity, recent studies have placed non-transcriptional pro-apoptotic activities of $\mathrm{p} 53$ at the center of an active debate to establish a comprehensive understanding of p53- mediated apoptosis (155).

\subsection{1. p53 role in transcription dependent apoptosis}

Several mechanisms have been implicated in p53-mediated apoptosis. p53 activation leads to upregulation of pro-apoptotic Bax and down-regulation of pro-survival factor Bcl-2 (156-157). More recently, it was demonstrated that p53-mediated apoptosis of M1 cells involves rapid activation of the pro-apoptotic Fas/CD95 death pathway-via up-regulation of membrane bound Fas (158) and the intrinsic mitochondrial pathway, which results in activation of caspase 8,9 , and 10. Fas blocking antibody or inhibition of the apical caspases 8 and 10 were almost effective in abrogating p53 mediated apoptosis, as that which occurs with IL-6. These observations suggest that $\mathrm{p} 53$ regulation of the $\mathrm{Bcl}-2$ members, Bax and $\mathrm{BcI}-2$, associated with the intrinsic mitochondrial apoptotic pathway is ancillary to the extrinsic Fas/CD95 apoptotic pathway in mediating p53 induced apoptosis of M1 myeloid leukemia cells (159). In other cell types, upregulation of IGF-BP3 has been associated with p53 mediated apoptosis by sequestering the cell survival factor, insulin-like growth factor-1 (160-161). The gene encoding for the cathepsin-D protease, PAG608, has also been implicated as a mediator of p53 induced apoptosis in 
various cell types (107). Furthermore, it has been documented that a series of p53-induced genes (PIG genes) encode proteins that respond to oxidative stress, suggesting that p53-mediated apoptosis involves activation of redox controlling targets followed by increase in ROS, oxidative damage to mitochondria, and consequent caspase activation (162). It has also been recently observed that p53 suppresses Nrf2-dependent transcription of antioxidant response genes, presumably, to prevent the generation of antioxidants that can hinder induction of apoptosis (163).

A number of p53 transcriptional targets represent genes with the potential to promote or inhibit apoptosis in stressed cells, such as BAX, PUMA, and NOXA, and the p53-repressed genes BCL2 and Survivin. Puma and Noxa are thought to indirectly induce mitochondrial outer membrane permeabilization (MOMP), induced by the activation of Bax and Bak, via interaction with prosurvival Bcl-2 family members interfering with Bax and Bak (164). Interestingly, it was observed that Puma and Noxa contribute differentially to the regulation of p53-mediated apoptotic pathways. In normal cells, Puma was found to induce mitochondrial outer membrane permeabilization via an ER-dependent pathway. However, upon E1A oncoprotein expression, cells also became susceptible to mitochondrial outer membrane permeabilization induction by Noxa via an ER-independent pathway (165). In addition, p53-dependent apoptosis can occur in the presence of inhibitors of transcription and translation (166). In recent years, it has become clear that p53 also harbors a direct pro-apoptotic function at the mitochondria via engaging in protein-protein interactions with anti- and pro-apoptotic $\mathrm{Bcl} 2$ family members, including BclXL and Bak (167).

\subsubsection{Role of $\mathbf{p 5 3}$ in transcription independent apoptosis}

It has been reported that certain transcriptionally inactive mutants of p53 can still induce apoptosis when over- expressed in tumor cells (168-169). Furthermore, in response to certain stresses such as hypoxia, p53 induces apoptosis but does not function as a transactivator (76). Intriguingly, Moll et al demonstrated that during p53dependent apoptosis a fraction of cellular p53 protein is localized into motochondria and induces release of cytochrome $\mathrm{C}$ whereas, this has not been observed during p53-mediated cell cycle arrest (167). Additional support to this finding has been gained from functional analysis of polymorphic variants of p53 (168). Within exon 4 of the p53 gene, a common single-nucleotide polymorphism (SNP) at codon 72 leads to the incorporation of either an arginine (R72) or a proline (P72) at this position of the protein. Further investigation has revealed that the R72 form of $\mathrm{p} 53$ induces apoptosis markedly better than the P72 variant (168). When potential mechanisms underlying the observed functional difference between the two p53 variants were explored, the greater apoptotic potential of the R72 form surprisingly correlated with its much better ability to traffic to mitochondria. Based on these data, it is possible to conclude that the enhanced apoptosis-inducing activity of the R72 protein is related, at least in part, to its greater mitochondrial localization. Consistently, an analysis of whole cell or mitochondrial extracts by
immunoprecipitation-Western blot analysis, demonstrated that the R72 form of $\mathrm{p} 53$ binds to the mitochondrial deatheffector protein BAK more effectively than to the P72 variant, correlating with the difference in apoptotic potential of the two p53 variants. Bak resides at mitochondria in healthy cells as an inactive monomer. In response to various death stimuli, it undergoes an activating allosteric conformational change that promotes homooligomerization. This leads to formation of a pore in the outer mitochondrial membrane, and allows the release of cytochrome $\mathrm{C}$ and other pro-apoptogenic factors from the mitochondria resulting in the activation of a caspase cascade (169). Two other BCL2 family members, BAX and BCL-XL, have also recently been implicated in mitochondrial induction of apoptosis caused by p53 (170171).

\section{DYSFUNCTION OF P53 TRAFFIC CONTROLLER IN HUMAN CANCER}

In the two decades since its original discovery, p53 has found a singularly prominent place in understanding human cancer. Although the biochemistry of p53 has been extensively studied, knowledge of the biological consequences of p53 dysfunction is still quite rudimentary. p53 dysfunction in cancer cells is mainly due to its mutations $(50 \%)$, epigenetic modulation at expression level, and low persistence of p53 protein level due to its enhanced turnover. Most p53 mutations found in human cancers are not null mutations but are responsible for mutant versions of the $\mathrm{p} 53$ protein that may have unwanted activities such as gain-of-function or dominant negative inhibitory activity for wild type p53. In many cases, this is achieved through polymorphisms and point mutations in p53, which often result in pronounced conformational changes. Such mutant polypeptides, which tend to accumulate at high levels in cancer cells, are believed to exert a dominant negative effect on normal p53. Other than polymorphism and mutation mediated inactivation, other mechanisms are also involved in inactivating expressed wild-type p53 such as virus infection and over-expression of dominant negative regulators of p53 family isoforms (e.g. DNp73 and other post-translational modifications of p53).

\subsection{Polymorphisms in TP53}

The cDNA for p53 was first cloned in 1984 (172-174), and then approximately 2 years later a mobility shift in p53 protein was identified due to a polymorphic sequence at amino acid 72 , changing proline to arginine (175-177). However, the polymorphism was deemed functionally insignificant. It was only in 1994, when allele frequencies of the proline 72 and arginine 72 variants (P72 and R72, respectively) in human populations were analyzed that Beckman et al noted statistically significant differences in allele frequency between different ethnic groups. For example, the P72 allele occurs in African Americans with a frequency of approximately $60 \%$ but only $30-35 \%$ in Caucasian Americans. Interestingly, Beckman noted that the P72 allele frequency increases linearly in multiple populations as they get close to the equator (178). This led to the hypothesis that the polymorphism at codon $72 \mathrm{might}$ have an impact on p53 function, and that the high degree of 
exposure to UV light near the equator is the cause for selection favoring the P72 allele. As other studies have suggested, in HPV-positive vulvar cancers, loss of 72P may occur as a result of the increased sensitivity of the wildtype $72 \mathrm{R}$ p53 protein to degradation, which is mediated by HPVE6, as also suggested for esophageal carcinomas (179180). The first comparison of the biological activity of endogenous P72 and R72 proteins was performed by Bonafe et al in 2002. They found that compared to P72, blood leukocytes, homozygous for R72, undergo increased apoptosis in response to the cytotoxic drug, cytosine arabinoside (181). However, further analysis revealed that the R72 variant demonstrated greatly increased trafficking to mitochondria according to findings reported by Marchenko et al. (167). A number of studies have attempted to determine whether or not there is an association between codon 72 polymorphic variants of TP53 and risk of particular cancer types. These studies have come to contradditory conclusions (182-187). The reasons for these discrepancies are not clear, but it can safely be said that they may be influenced by unknown variables not examined in such studies. A second exonic polymorphism at codon 47 , changing a proline to serine, has also been described (188-189). The frequency of this polymorphism is very low, ranging in various studies from $0.5 \%$ to $5 \%$. This polymorphism is close to serine 46 , a phosphorylation site crucial in the apoptotic function of $\mathrm{p} 53$ (189). The clinical significance of this p53 variant is still unknown.

\subsection{Mutations in TP53}

The p53 tumor suppressor gene is mutated in about half $(50 \%)$ of all cancer types arising in a variety of tissues, and it manifests a high frequency of missense mutations (136, 138, and 190). Non-missense mutations are also found in the p53 gene but at a lower frequency compared to those present in other tumor suppressor genes such as APC, BRCA, and ATM. These types of mutations occur in the distribution of missense mutations rather more frequently in exons 2-4 (54\%) and 9-11 (77\%) than in exons 5-8 (20\%). Multiple point mutations in the $\mathrm{N}$ terminus of the p53 protein are required to inactivate its transcriptional transactivation function (191) and mutations in the carboxy-terminus modify the oligomerization and nuclear localization of the p53 protein (192-194), the recognition of DNA damage (142-143), the negative regulation of $\mathrm{p} 53$ binding to promoter sequences of genes regulated by $\mathrm{p} 53$, the transcription of $\mathrm{p} 53$-transactivated genes (195), and the induction of apoptosis (196). More studies on p53 mutation analysis have demonstrated that some carcinogens are able to cause specific mutations. The occurrence of characteristic p53 mutation spectra upon exposure to a particular carcinogen can add to the 'weight of the evidence' implicating an environmental pollutant contaminant in the etiology of human cancer (190).

\subsection{Virus infections}

The study and use of DNA virus proteins that inactivate p53 have provided fundamental insights into tumorigenesis. Several tumor-inducing human viruses, including certain small DNA viruses (adenoviruses, polyomaviruses, papillomaviruses 16 and 18 , and the viruses hepatitis $\mathrm{B}$ and $\mathrm{C}$ ), large DNA viruses (cytomegalovirus, herpes virus 6 and 8, Epstein-bar virus) (197) and human retroviruses (HTLV-1 and HTLV-2) (198) adopt various mechanisms for p53 down-regulation. The tumor viruses such as adenovirus, SV40, and human papillomaviruses encode proteins which affect p53 stabilization and activity at multiple levels to facilitate viral replication and preventing premature death of infected cells. Although the Adenovirus E1B-19K protein can block apoptosis downstream of p53 (199), most of the small DNA tumor viruses encode proteins that target p53 directly. SV40 LT binds and inactivates p53 directly (200-201), and p53 was first identified as a cellular protein that interacts with SV40 LT (202-203). Adenovirus encodes two viral proteins, EIB-55K and E4-ORF 6 that form a complex, and together with cellular proteins are involved in ubiquitination (cullin 5, RBC, Elongin), and the binding and degradation of p53 (204-205). The HPV E6 protein also degrades p53 by binding to both $\mathrm{p} 53$ and the cellular E3 ubiquitin ligase, while E6AP does not normally function to degrade p53, and HPVE6 recruits and redirects its ubiquitin ligase activity to degrade p53 (206-207). Thus, disparate DNA viruses functionally converge to encode proteins that bind and inactivate p53, underscoring the importance of the $\mathrm{p} 53$ tumor suppressor pathway in monitoring normal cell growth and DNA replication (208-210). Further, Ferbeyre et al (211) found that adenovirus E1A protein circumvents Ras-induced senescence by interfering not only with $\mathrm{p} 53$ and $\mathrm{Rb}$ but also with promyelocytic leukemia protein (PML bodies). In particular, these authors found that PML upregulation is abolished and the shape and number of nuclear bodies (NBs) are changed into E1A-expressing cells. Moreover, in some cells, a fraction of the PML protein is relocalized into the cytoplasm. Regulation of p53 and PML by viruses might not be exclusive to adenoviruses. Interestingly, the SV40 large tumor antigen has been reported to relocalize p53 to structures that are juxtaposed with PML-containing bodies (212) and viral proteins, such as IE1 and IE2 from hCMV, or E4 or F3 of adenovirus, and disrupt NBs (213-214). In addition, relocalization of PML into the cytoplasm after infection by other viruses has been documented (215-216). Polyomavirus and SV40 are both closely related members of the Polyomaviridae family. In contrast to SV40, polyomavirus is unusual among the small DNA tumor viruses because none of its three early region proteins (PyLT, PyMT, PyST) directly binds and inactivates p53 (217). Nevertheless, PyMT induces ARF and consequently activates a p53 dependent checkpoint that prevents PyMT-mediated transformation of primary mouse cells, and also of rat REF52 cells (218). A recent study resolves the disparity and singularity of polyoma viral proteins that apparently fail to directly bind and inactivate p53 or disrupt the p53 downstream pathway. This study shows that PyST prevents the activation of p53 through its key upstream regulator, ARF. The PyST PP2A interacting domain plays a critical role in preventing ARF mediated activation of $\mathrm{p} 53$, implicating a previously unrecognized role for PP2A in the modulation of the ARF-p53 tumor suppressor pathway (219).

\section{4. p53 family isoforms}

The identification of the two p53-related genes, p63 and p73, initially provoked speculation that all three 
genes might play an analogous role in human tumors (220222). In particular, the striking homology among the family members within both their DNA binding domain (DBD) and oligomerization domain (OD) suggests that these genes might regulate transcription of a common subset of target genes by binding to common promoters as either homo- or heterotetrameric complexes. However, work in the ensuing years has revealed a much more complex picture of the contribution of p63 and p73 to human cancer. A major part of this complexity stems from the expression of both DN and TA isoforms of p63 and p73 in many human tumors. Such studies support the view that TAp63/TAp73 isoforms, like $\mathrm{p} 53$, exhibit tumor suppressive properties, and that upregulation of $\mathrm{DNp} 63 / \mathrm{DNp} 73$ isoforms is a common mechanism of their inactivation during tumorigenesis. Indeed, important physical and functional interactions among family members have now been demonstrated in tumor-specific contexts (223-226). In ectopic expression studies, heteromeric complexes have been demonstrated between different isoforms of the same gene, TAp63/ DNp73 and TAp73 / DNp63 isoforms $(224,226)$. In each case, the respective DN isoforms function as potent inhibitors of transactivation by the respective TA isoforms, and consistent with these findings, endogenous complexes have also been demonstrated between different p73 isoforms, and between DNp63 and TAp73 (227-228). Wild-type p53 binds to p63 and p73 with much lower affinity than p63 and p73 bind one to the other (229). However, despite the absence of strong physical interaction, it seems highly plausible that in some tumor contexts both DNp63 and DNp73 serve to inhibit the function of p53 through promoter competition or other indirect mechanisms $(4,5,230)$.

\section{SUMMARY AND PERSPECTIVE}

A great deal has been learned about p53 protein and its participation in different cell signaling pathways. It is likely that p53 protein can cause virtually all cells, including normal to cancer cells, to adopt different cell fates. In general, p53 has been considered to be a tumor suppressor due to its ability to induce cell cycle inhibition and/or apoptosis. However, this may not be necessarily the case because p53 deficient cells can also execute cell cycle inhibition and/or apoptosis. Moreover, p53 knock-out mice develop normally with minor malfunctions but are prone to cancer. Insights from emerging data indicate that, in addition to tumor suppression p53 protein induces apoptosis and/or cell cycle inhibition. It is also possible that p53 deficiency can have secondary effects on metabolism and/or other effects in predisposition to cancer. Majority of cancers arise in the presence of an inactive p53 (mainly by mutation) and consequently, introduction of wild-type p53 into those cells can induce apoptosis and/or senescence depending on the cellular system.

Therapeutic strategies which result in the activation of p53 would benefit from an ability to modulate or at least take advantage of the differential responses to p53 activation. The availability of small molecule modulators of p53 activity will allow the planning of more sophisticated treatment options, involving the temporal manipulation of p53 activity, avoiding therapy-induced toxicity and retaining $\mathrm{p} 53$-dependent protection from tumor development (321). It is hoped that understanding of how p53 activation can be controlled will help in designing more effective and less toxic treatment options.

On the basis of available data, it can be concluded that p53 is acting as a main traffic controller in a network of cell signaling pathways. Corruption of these signaling pathways leads to immortalization and consequently to death of the host.

\section{REFERENCES.}

1. A. B. DeLeo, G. Jay, E. Appella, G.C. Dubois, L.W. Law, L.J. Old: Detection of a transformation-related antigen in chemically induced sarcomas and other transformed cells of the mouse. Proc Natl Acad Sci U S A 76, 2420-4 (1979)

2. D. Eliyahu, A. Raz, P. Gruss, D. Givol, M. Oren: Participation of p53 cellular tumour antigen in transformation of normal embryonic cells. Nature 312, 646-9 (1984)

3. S.J. Baker, E.R. Fearon, J.M. Nigro, S.R. Hamilton, A.C. Preisinger, J.M. Jessup, P. vanTuinen, D.H. Ledbetter, D.F. Barker, Y. Nakamura, R. White, B. Vogelstein: Chromosome 17 deletions and p53 gene mutations in colorectal carcinomas. Science 244, 217-21(1989)

4. V. Graupner, K. Schulze-Osthoff, F. Essmann, R.U. Jänicke: Functional characterization of p53beta and p53gamma, two isoforms of the tumor suppressor p53. Cell Cycle 8, 1238-48 (2009)

5. R. Accardi, W. Dong, A. Smet, R. Cui, A. Hautefeuille,A.S. Gabet,B.S. Sylla, L. Gissmann, P. Hainaut, M. Tommasino: Skin human papillomavirus type 38 alters p53 functions by accumulation of deltaNp73. EMBO Rep 7, 334-340 (2006).

6. A.I. Zaika, N. Slade, S.H. Erster, C. Sansome, T.W. Joseph, M. Pearl, E. Chalas, U.M. Moll: DeltaNp73, a dominant-negative inhibitor of wild-type p53 and TAp73, is up-regulated in human tumors. J Exp Med 196, 765-80 (2002)

7. J. A. Royds, B. Iacopetta: p53 and disease: when the guardian angel fails. Cell Death Differ 13, 1017-1026 (2006)

8. B. Vogelstein, D. Lane, A. J. Levine: Surfing the p53 network. Nature 408, 307-310 (2000)

9. L. A. Donehower: The p53-deficient mouse: a model for basic and applied cancer studies. Sem Cancer Biol 7, 269278 (1996)

10. E. C. Pietsch, O. Humbey, \& M. E. Murphey: Polymorphisms in the p53 pathway. Oncogene 25, 16021611 (2006) 
11. O. Lapenko, C. Prives: Transcriptional regulation by p53: one protein, many possibilities. Cell Death Differ 13, 951-961 (2006)

12. S. Cawley, S. Bekiranov, H.H. Ng, P. Kapranov, E.A. Sekinger, D. Kampa, A. Piccolboni, V. Sementchenko, J. Cheng, A.J. Williams, R. Wheeler, B. Wong, J. Drenkow, M. Yamanaka, S. Patel, S. Brubaker, H. Tammana, G. Helt, K. Struhl, T.R. Gingeras: Unbiased mapping of transcription factor binding sites along human chromosomes 21 and 22 points to widespread regulation of noncoding RNAs. Cell 116, 499-509 (2004)

13. C. L. Wei, Q. Wu, V.B. Vega, K.P. Chiu, P. Ng, T. Zhang, A. Shahab, H.C. Yong, Y. Fu, Z. Weng, J. Liu, X.D. Zhao, J.L. Chew, Y.L. Lee, V.A. Kuznetsov, W.K. Sung, L.D. Miller, B. Lim, E.T. Liu, Q. Yu, H.H. Ng, Y. Ruan: A global map of p53 transcriptionfactor binding sites in the human genome. Cell 124, 207-219 (2006)

14. S. Matoba, J.G. Kang, W.D. Patino, A. Wragg, M. Boehm, O. Gavrilova, P.J. Hurley, F. Bunz, P.M. Hwang: p53 regulates mitochondrial respiration. Science 312, $1650-1653$ (2006)

15. K. Bensaad, A. Tsuruta, M.A. Selak, M.N. Vidal, K. Nakano, R. Bartrons, E. Gottlieb, K.H. Vousden: TIGAR, a p53-inducible regulator of glycolysis and apoptosis. Cell 126, 107-120 (2006)

16. D. Crighton, S. Wilkinson, J. O'Prey, N. Syed, P. Smith, P.R. Harrison, M. Gasco, O. Garrone, T. Crook, K.M. Ryan: DRAM, a p53-induced modulator of autophagy, is critical for apoptosis. Cell 14, 121-134 (2006)

17. S. A. Gatz, L. Wiesmuller: p53 in recombination and repair. Cell Death Differ 13, 1003-1016 (2006)

18. K. Bensaad, K. H. Vousden: Savior and slayer: the two faces of p53. Nature Med 11, 1278-1279 (2005)

19. L. Roger, G. Gadea, P. Roux: Control of cell migration: a tumour suppressor function for p53?. Biol Cell 98, 141-152 (2006)

20. R. M. Kortleverm, P. J. Higgins, R. Bernards: Plasminogen activator inhibitor- 1 is a critical downstream target of $\mathrm{p} 53$ in the induction of replicative senescence. Nature Cell Biol. 8, 877-884 (2006)

21. J. G. Toeodoro, A. E. Parker, X. Zhu, M. R. Green: p53mediated inhibition of angiogenesis through upregulation of a collagen prolyl hydroxylase. Science 313, 968-971 (2006)

22. F. Murray-Zmijewski, D. P. Lane, J. C. Bourdon: p53/p63/p73 isoforms: an orchestra of isoforms to harmonise cell differentiation and response to stress. Cell Death Differ 13, 962-972 (2006)

23. X. Wang, H.Y. Kua, Y. Hu, K. Guo, Q. Zeng, Q. Wu, H.H. Ng, G. Karsenty, B. de Crombrugghe, J. Yeh, B. Li: p53 functions as a negative regulator of osteoblastogenesis, steoblast-dependent osteoclastogenesis, and bone remodeling. J Cell Biol 172, 115-125 (2006)

24. W. Nordstrom, J.M Abrams: Guardian ancestry: fly p53 and damage-inducible apoptosis. Cell Death Differ 7, 1035$1038(2000)$

25. W.B. Derry, A.P. Putzke, J.H. Rothman: Caenorhabditis elegans p53: role in apoptosis, meiosis, and stress resistance. Science 294, 591-595 (2001)

26. B. Schumacher, K. Hofmann, S. Boulton, A. Gartner: The C. elegans homolog of the p53 tumor suppressor is required for DNA damage-induced apoptosis. Curr Biol 11, 1722-1727 (2001)

27. A.J. Levine, W. Hu, Z. Feng: The P53 pathway: what questions remain to be explored?. Cell Death Differ 13, 1027-1036 (2006)

28. T. Kamijo, S. Bodner, E. van de Kamp, D.H. Randle, C.J. Sherr: Tumor spectrum in ARF-deficient mice. Cancer Res 59, 2217-2222 (1999)

29. L. Moore, S. Venkatachalam, H. Vogel, J.C. Watt, C.L. $\mathrm{Wu}, \quad$ H. Steinman, S.N. Jones, L.A. Donehower: Cooperativity of p19ARF, Mdm2, and p53 in murine tumorigenesis. Oncogene 22, 7831-7837 (2003)

30. M.A. Lohrum, R.L. Ludwig, M.H. Kubbutat, M. Hanlon, K.H. Vousden: Regulation of HDM2 activity by the ribosomal protein L11. Cancer Cell 3, 577-587 (2003)

31. M.A. Christophorou, I. Ringshausen, A.J. Finch, L.B. Swigart, G.I. Evan: The pathological response to DNA damage does not contribute to p53-mediated tumour suppression. Nature 443, 214-217 (2006)

32. A. Efeyan, I. Garcia-Cao, D. Herranz, S. VelascoMiguel, M. Serrano: Policing of oncogene activity by p53. Nature 443, 159-160 (2006)

33. W. Maltzman, L. Czyzyk: UV irradiation stimulates levels of p53 cellular tumor antigen in nontransformed mouse cells. Mol Cell Biol 4, 1689-1694 (1984)

34. D.P. Lane: Cancer p53, guardian of the genome. Nature $358,15-16(1992)$

35. J.D. Siliciano, C.E Canman, Y. Taya, K. Sakaguchi, E, Appella, M.B. Kastan: DNA damage induces phosphorylation of the amino terminus of p53. Genes Dev 11, 3471-3481 (1997)

36. C. Chao, S. Saito, C.W. Anderson, E. Appella, Y. Xu: Phosphorylation of murine p53 at ser- 8 regulates the p53 responses to DNA damage. Proc Natl Acad Sci USA 97, 11936-11941 (2000)

37. S. Saito, A.A. Goodarzi, Y. Higashimoto, Y. Noda, S.P. Lees-Miller, E. Appella, C.W. Anderson: ATM mediates phosphorylation at multiple p53 sites, including Ser(46), in 
response to ionizing radiation. $J$ Biol Chem 277, 1249112494 (2002)

38. E.U. Kurz, S.P Lees-Miller: DNA damage-induced activation of ATM and ATM- dependent signaling pathways. DNA Repair 3, 889-900 (2004)

39. J. Bartkova, Z. Horejsi, K. Koed, A. Kramer, F. Tort, K. Zieger, P. Guldberg, M. Sehested, J.M. Nesland, C. Lukas, T. Orntoft, J. Lukas, J. Bartek: DNA damage response as a candidate anti-cancer barrier in early human tumorigenesis. Nature 434, 864-870 (2005)

40. V.G. Gorgoulis, L.V. Vassiliou, P. Karakaidos, P. Zacharatos, A. Kotsinas, T. Liloglou, M. Venere, R.A. Ditullio Jr, N.G. Kastrinakis, B. Levy, D. Kletsas, A. Yoneta, M. Herlyn, C. Kittas, T.D. Halazonetis: Activation of the DNA damage checkpoint and genomic instability in human precancerous lesions. Nature 434, 907-913 (2005)

41. A.L. Jackson, L.A. Loeb: The contribution of endogenous sources of DNA damage to the multiple mutations in cancer. Mutat Res 477, 7-21 (2001)

42. J. Bartkova, N. Rezaei, M. Liontos, P. Karakaidos, D. Kletsas, N. Issaeva, L.V. Vassiliou, E. Kolettas, K. Niforou, V.C. Zoumpourlis, M. Takaoka, H. Nakagawa, F. Tort, K. Fugger, F. Johansson, M. Sehested, C.L. Andersen, L. Dyrskjot, T. Orntoft, J. Lukas, C. Kittas, T. Helleday, T.D. Halazonetis, J. Bartek, V.G. Gorgoulis: Oncogeneinduced senescence is part of the tumorigenesis barrier imposed by DNA damage checkpoints. Nature 444, 633637 (2006)

43. R. Di Micco, M. Fumagalli, A. Cicalese, S. Piccinin, P. Gasparini, C. Luise, C. Schurra, M. Garre, P.G. Nuciforo, A. Bensimon, R. Maestro, P.G. Pelicci, F. d'Adda di Magagna: Oncogene-induced senescence is a DNA damage response triggered by DNA hyper-replication. Nature 444, 638- 642 (2006)

44. C. Chao, D. Herr, J. Chun, Y. Xu: Ser18 and 23 phosphorylation is required for p53- ependent apoptosis and tumor suppression. Embo $J$ 25, 2615-2622 (2006)

45. L.A. Donehower, M. Harvey, B.L. Slagle, M.J. McArthur, C.A. Montgomery Jr, J.S. Butel, A. Bradley: Mice deficient for p53 are developmentally normal but susceptible to spontaneous tumours. Nature 356 215-221 (1992)

46. T. Jacks, L. Remington, B.O. Williams, E.M. Schmitt, S. Halachmi, R.T. Bronson, R.A. Weinberg: Tumor spectrum analysis in p53-mutant mice. Curr Biol 4, 1-7 (1994)

47. D.M. Milne, L.E. Campbell, D.G. Campbell, D.W. Meek: p53 is phosphorylated in vitro and in vivo by an ultraviolet radiation-induced protein kinase characteristic of the c-Jun kinase, JNK1. J Biol Chem 270 5511- 5518 (1995)
48. M.C. Hu, W.R. Qiu, Y.P. Wang: JNK1, JNK2 and JNK3 are p53 N-terminal serine 34 kinases. Oncogene 15, 2277-2287 (1997)

49. S.Y. Fuchs, V. Adler, M.R. Pincus, Z. Ronai: MEKK1/JNK signaling stabilizes and activates p53. Proc Natl Acad Sci USA 95, 10541-10546 (1998)

50. D.V. Bulavin, S. Saito, M.C. Hollander, K. Sakaguchi, C.W Anderson, E. Appella, A.J. Jr Fornace: Phosphorylation of human p53 by p38 kinase coordinates $\mathrm{N}$-terminal phosphorylation and apoptosis in response to UV radiation. EMBO J 18, 6845-6854 (1999)

51. T. Buschmann, O. Potapova, A. Bar-Shira, V.N. Ivanov, S.Y. Fuchs, S. Henderson, V.A. Fried, T. Minamoto, D. Alarcon-Vargas, M.R. Pincus, W.A. Gaarde, N.J. Holbrook, Y. Shiloh, Z. Ronai: Jun NH2-terminal kinase phosphorylation of $\mathrm{p} 53$ on Thr- 81 is important for p53 tabilization and transcriptional activities in response to stress. Mol Cell Biol 21, 2743-2754 (2001)

52. S.L. Harris, A.J. Levine: The p53 pathway: Positive and negative feedback loops. Oncogene 24, 2899-2908 (2005)

53. S. Ingvarsson, B.I. Sigbjornsdottir, C. Huiping, S.H. Hafsteinsdottir, G. Ragnarsson, R.B. Barkardottir, A. Arason, V. Egilsson, J.T. Bergthorsson: Mutation analysis of the CHK2 gene in breast carcinoma and other cancers. Breast Cancer Res 4, R4 (2002)

54. J. Bartek, J. Lukas: Chk1 and Chk2 kinases in checkpoint control and cancer. Cancer Cell 3, 421-429 (2003)

55. J. Feng, J. Yan, J. Chen, G. Schlake, Z. Jiang, C.H. Buzin, S.S. Sommer, A. Dritschilo: Absence of somatic ATM missense mutations in 58 mammary carcinomas. Cancer Genet Cytogenet 145, 179-182 (2003)

56. F. Gumy-Pause, P. Wacker, A.P. Sappino: ATM gene and lymphoid malignancies. Leukemia 18, 238-242 (2004)

57. C. Greenman, P. Stephens, R. Smith, G.L. Dalgliesh, C. Hunter, G. Bignell, H. Davies, J. Teague, A. Butler, C. Stevens, S. Edkins, S. O'Meara, I. Vastrik, E.E. Schmidt, T. Avis, S. Barthorpe, G. Bhamra, G. Buck, B. Choudhury, J. Clements, J. Cole, E. Dicks, S. Forbes, K. Gray, K. Halliday, R. Harrison, K. Hills, J. Hinton, A. Jenkinson, D. Jones, A. Menzies, T. Mironenko, J. Perry, K. Raine, D. Richardson, R. Shepherd, A. Small, C. Tofts, J. Varian, T. Webb, S. West, S. Widaa, A. Yates, D.P. Cahill, D.N. Louis, P. Goldstraw, A.G. Nicholson, F. Brasseur, L. Looijenga, B.L. Weber, Y.E. Chiew, A. DeFazio, M.F. Greaves, A.R. Green, P. Campbell, E. Birney, D.F. Easton, G. Chenevix-Trench, M.H. Tan, S.K. Khoo, B.T. Teh, S.T. Yuen, S.Y. Leung, R. Wooster, P.A. Futreal, M.R. Stratton: Patterns of somatic mutation in human cancer genomes. Nature 446, 153-158 (2007)

58. M. Serrano, A.W. Lin, M.E. McCurrach, D. Beach, S.W. Lowe: Oncogenic ras provokes premature cell 
senescence associated with accumulation of p53 and p16INK4a. Cell 88, 593-602 (1997)

59. C.J. Sherr. The INK4a/ARF network in tumour suppression. Nat Rev Mol Cell Biol 2, $731-737$ (2001)

60. I. Palmero, C. Pantoja, M. Serrano: p19ARF links the tumour suppressor p53 to Ras. Nature 395, 125-126 (1998)

61. E. de Stanchina, M.E. McCurrach, F. Zindy, S.Y. Shieh, G. Ferbeyre, A.V. Samuelson, C. Prives, M.F. Roussel, C.J, Sherr, S.W. Lowe: E1A signaling to p53 involves the p19(ARF) tumor suppressor. Genes Dev 12, 2434-2442 (1998)

62. F. Zindy, C.M. Eischen, D.H. Randle, T. Kamijo, J.L. Cleveland, C.J. Sherr, M.F. Roussel: Myc signaling via the ARF tumor suppressor regulates p53- dependent apoptosis and immortalization. Genes Dev 12, 2424- 2433 (1998)

63. N.E. Sharpless: INK4a/ARF: A multifunctional tumor suppressor locus. Mutat Res 576, 22-38 (2005)

64. J. Gil, G. Peters: Regulation of the INK4b-ARF-INK4a tumour suppressor locus: All for one or one for all. Nat Rev Mol Cell Biol 7, 667-677 (2006)

65. K. Inoue, M.F. Roussel, C.J. Sherr: Induction of ARF tumor suppressor gene expression and cell cycle arrest by transcription factor DMP1. Proc Natl Acad Sci USA 96, 3993-3998 (1999)

66. K. Inoue, R. Wen, J.E. Rehg, M. Adachi, J.L. Cleveland, M.F. Roussel, C.J. Sherr: Disruption of the ARF transcriptional activator DMP1 facilitates cell immortalization, Ras transformation, and tumorigenesis. Genes Dev 14, 1797-1809 (2000)

67. T. Kamijo, F. Zindy, M.F. Roussel, D.E. Quelle, J.R. Downing, R.A. Ashmun, G. Grosveld, C.J. Sherr: Tumor suppression at the mouse INK4a locus mediated by the alternative reading frame product p19ARF. Cell 91, 649659 (1997)

68. T. Kamijo, S. Bodner, E. van de Kamp, D.H. Randle, C.J. Sherr: Tumor spectrum in ARF-deficient mice. Cancer Res 59, 2217-2222 (1999)

69. J.A. Randerson-Moor, M. Harland, S. Williams, D. Cuthbert-Heavens, E. Sheridan, J. Aveyard, K. Sibley, L. Whitaker, M. Knowles, J.N. Bishop, D.T. Bishop: A germline deletion of p14(ARF) but not CDKN2A in a melanomaneural system tumour syndrome family. Hum Mol Genet 10, 55- 62 (2001)

70. H. Rizos, S. Puig, C. Badenas, J. Malvehy, A.P. Darmanian, L. Jimenez, M. Mila, R.F. Kefford: A melanoma-associated germline mutation in exon lbeta inactivates p14ARF. Oncogene 20, 5543-5547 (2001)

71. W.Y. Kim, N.E. Sharpless: The regulation of INK4/ARF in cancer and aging. Cell 127, 265-275 (2006)
72. O. Vafa, M. Wade, S. Kern, M. Beeche, T.K. Pandita, G.M. Hampton, G.M. Wahl: c-Myc can induce DNA damage, increase reactive oxygen species, and mitigate p53 function: a mechanism for oncogene-induced genetic instability. Mol Cell 9, 1031-1044 (2002)

73. G. Ferbeyre, E. de Stanchina, A.W. Lin, E. Querido, M.E. McCurrach, G.J. Hannon, S.W. Lowe: Oncogenic ras and p53 cooperate to induce cellular senescence. Mol Cell Biol 22, 3497-3508 (2002)

74. D.V. Bulavin, O.N. Demidov, S. Saito, P. Kauraniemi, C. Phillips, S.A. Amundson, C. Ambrosino, G. Sauter, A.R. Nebreda, C.W. Anderson, A. Kallioniemi, A.J. Fornace Jr, E. Appella: Amplification of PPM1D in human tumors abrogates p53 tumor-suppressor activity. Nat Genet 31, 210-215 (2002)

75. R. Alarcón, C. Koumenis, R.K. Geyer, C.G. Maki, A.J. Giaccia: Hypoxia induces p53 accumulation through MDM2 down-regulation and inhibition of E6-mediated degradation. Cancer Res 59, 6046-6051 (1999)

76. C. Koumenis, R. Alarcon, E. Hammond, P. Sutphin, W. Hoffman, M. Murphy, J. Derr, Y. Taya, S.W. Lowe, M. Kastan, A. Giaccia: Regulation of p53 by hypoxia: dissociation of transcriptional repression and apoptosis from p53-dependent transactivation. Mol Cell Biol 21, 1297- 1310 (2001)

77. E.M. Hammond, N.C. Denko, M.J. Dorie, R.T. Abraham, A.J. Giaccia: Hypoxia links ATR and p53 through replication arrest. Mol Cell Biol 22, 1834-1843 (2002)

78. Q.A. Khan, R. Agarwal, A. Seidel, H. Frank, K.H. Vousden, A. Dipple: DNA adduct levels associated with p53 induction and delay of MCF-7 cells in S phase after exposure to benzo[g]chrysene dihydrodiol epoxide enantiomers. Mol Carcinog 23, 115-120 (1998)

79. A.A. Sablina, P.M. Chumakov, A.J. Levine, B.P. Kopnin: p53 activation in response to microtubule disruption is mediated by integrin-Erk signalling. Oncogene 20, 899-909 (2001)

80. Z.A. Stewart, L.J. Tang, J.A. Pietenpol: Increased p53 phosphorylation after microtubule disruption is mediated in a microtubule inhibitor- and cell-specific manner. Oncogene 20, 113-124 (2001)

81. G. Damia, L. Filiberti, F. Vikhanskaya, L. Carrassa, Y. Taya, M. D'incalci, M. Broggini: Cisplatinum and taxol induce different patterns of $\mathrm{p} 53$ phosphorylation. Neoplasia $3,10-16(2001)$

82. K. Webley, J.A. Bond, C.J. Jones, J.P. Blaydes, A. Craig, T. Hupp, D. Wynford-Thomas: Posttranslational modifications of p53 in replicative senescence overlapping but distinct from those induced by DNA damage. Mol Cell Biol 20, 2803-2808 (2000) 
83. A.M. Bode, Z. Dong: Post-translational modification of p53 in tumorigenesis. Nature Rev Cancer 4, 793-805 (2004)

84. Y.H. Ou, P.H. Chung, T.P. Sun, S.Y. Shieh: p53 Cterminal phosphorylation by CHK1 and CHK2 participates in the regulation of DNA-damage-induced C-terminal acetylation. Mol Biol Cell 16, 1684-1695 (2005)

85. E.S. Stavridi, N.H Chehab, A. Malikzay, T. D. Halazonetis: Substitutions that compromise the ionizing radiation-induced association of p53 with 14-3-3 proteins also compromise the ability of p53 to induce cell cycle arrest. Cancer Res 61, 7030-7033 (2001)

86. O. Bischof, K. Schwamborn, N. Martin, A. Werner, C. Sustmann, R. Grosschedl, A._Dejean: The E3 SUMO ligase PIASy is a regulator of cellular senescence and apoptosis. Mol Cell 22, 783-794 (2006)

87. V. Di Stefano, S. Soddu, A. Sacchi, G. D’Orazi: HIPK2 contributes to PCAF- ediated acetylation and selective transactivation of p21af1 after nonapoptotic DNA damage. Oncogene 24, 5431-5442 (2005)

88. C.D. Knights, J. Catania, S. Di Giovanni, S. Muratoglu, R. Perez, A. Swartzbeck, A.A. Quong, X. Zhang, T. Beerman, R.G. Pestell, M.L. Avantaggiati: Distinct p53 acetylation cassettes differentially influence gene-expression patterns and cell fate. J Cell Biol 173, 533-544 (2006)

89. L. Le Cam, L.K. Linares, C. Paul, E. Julien, M. Lacroix, E. Hatchi, R. Triboulet, G. Bossis, A. Shmueli, M.S. Rodriguez, O. Coux, C. Sardet: E4F1 is an atypical ubiquitin ligase that modulates p53 effector functions independently of degradation. Cell 127, 775-788 (2006)

90. K. Sakaguchi, J.E. Herrera, S. Saito, T. Miki, M. Bustin, A. Vassilev, C.W. Anderson, E. Appella: DNA damage activates p53 through a phosphorylationacetylation cascade. Genes Dev 12, 2831-2841 (1998)

91. S. Chuikov, J.K. Kurash, J.R. Wilson, B. Xiao, N. Justin, G.S. Ivanov, K. McKinney, P. Tempst, C. Prives, S.J. Gamblin, N.A. Barlev, D. Reinberg: Regulation of p53 activity through lysine methylation. Nature 432, 353-360 (2004)

92. S. St Clair, L. Giono, S. Varmeh-Ziaie, L. ResnickSilverman, W.J. Liu, A. Padi, J. Dastidar, A. DaCosta, M. Mattia, J.J. Manfredi: DNA damage-induced downregulation of $\mathrm{Cdc} 25 \mathrm{C}$ is mediated by p53 via two independent mechanisms: one involves direct binding to the cdc25C promoter. Mol Cell 16, 725-736 (2004)

93. R.A. Johnson, T.A. Ince, K.W. Scotto: Transcriptional repression by $\mathrm{p} 53$ through direct binding to a novel DNA element. J Biol Chem 276, 27716-27720 (2001)

94. A. Mirza, Q. Wu, L. Wang, T. McClanahan, W.R. Bishop, F. Gheyas, W. Ding, B. Hutchins, T. Hockenberry,
P. Kirschmeier, J.R. Greene, S. Liu: Global transcriptional program of p53 target genes during the process of apoptosis and cell cycle progression. Oncogene 22, 3645-3654 (2003)

95. H.J. Im, T.A. Craig, M.R. Pittelkow, R. Kumar: Characterization of a novel hexameric repeat DNA sequence in the promoter of the immediate early gene, IEX1, that mediates 1alpha,25-dihydroxyvitamin $\mathrm{D}(3)$ associated IEX-1 gene repression. Oncogene 21, 3706-3714 (2002)

96. A.C. Chun, D.Y. Jin: Transcriptional regulation of mitotic checkpoint gene MAD1 by p53. J Biol Chem 278, 37439-37450 (2003)

97. T.F. Burns, P. Fei, K.A. Scata, D.T Dicker, W.S. ElDeiry. Silencing of the novel p53 target gene Snk/Plk2 leads to mitotic catastrophe in paclitaxel (taxol)-exposed cells. Mol Cell Biol 23, 5556-5571 (2003)

98. V. Golubovskaya, A. Kaur, W. Cance: Cloning and characterization of the promoter region of human focal adhesion kinase gene: nuclear factor kappa B and p53 binding sites. Biochim Biophys Acta 1678, 111-125 (2004)

99. D.W. Zhang, K.T. Jeang, C.G. Lee: p53 negatively regulates the expression of FAT10, a gene upregulated in various cancers. Oncogene 25, 2318-2327 (2006)

100. M. Sachdeva, S. Zhu, F. Wu, H. Wu, V. Walia, S. Kumar, R. Elble, K. Watabe, Y.Y. Mo: p53 represses cMyc through induction of the tumor suppressor miR-145. Proc Natl Acad Sci US A 106, 3207-3212 (2009)

101. N.V. Sankpal, M.W. Willman, T.P. Fleming, J.D. Mayfield, W.E. Gillanders: Transcriptional repression of epithelial cell adhesion molecule contributes to p53 control of breast cancer invasion. Cancer Res 69, 753-757 (2009)

102. S. Sohr, K. Engeland: RHAMM is differentially expressed in the cell cycle and downregulated by the tumor suppressor p53. Cell Cycle 7, 3448-3460 (2008)

103. M.J. Scian, E.H. Carchman, L. Mohanraj, K.E. Stagliano, M.A. Anderson, D. Deb, B.M. Crane, T. Kiyono, B. Windle, S.P. Deb, S. Deb: Wild-type p53 and p73 negatively regulate expression of proliferation related genes. Oncogene 27, 2583-2593 (2008)

104. F. Alimirah, R. Panchanathan, J. Chen, X. Zhang, S.M. Ho, D. Choubey: Expression of androgen receptor is negatively regulated by p53. Neoplasia 9, 1152-1159 (2007)

105. M. Wu, L.G. Xu, T. Su, Y. Tian, Z. Zhai, H.B. Shu: AMID is a p53-inducible gene downregulated in tumors. Oncogene 23, 6815-6819 (2004)

106. K. Nakano, K.H. Vousden: PUMA, a novel proapoptotic gene, is induced by p53. Mol Cell 7, 683-694 (2001) 
107. G.S. Wu, P. Saftig, C. Peters, W.S. El-Deiry: Potential role for cathepsin D in p53-dependent tumor suppression and chemosensitivity. Oncogene 16, 2177-2183 (1998)

108. M. Dohn, J. Jiang, X. Chen: Receptor tyrosine kinase EphA2 is regulated by p53-family proteins and induces apoptosis. Oncogene 20, 6503-6515 (2001)

109. W.S. el-Deiry, T. Tokino, T. Waldman, J.D. Oliner, V.E. Velculescu, M. Burrell, D.E. Hill, E. Healy, J.L. Rees, S.R. Hamilton, et al: Topological control of p21WAF1/CIP1 expression in normal and neoplastic tissues. Cancer Res 55, 2910-2919 (1995)

110. A. Saramäki, C.M. Banwell, M.J. Campbell, C. Carlberg: Regulation of the human p21(wafl/cip1) gene promoter via multiple binding sites for $\mathrm{p} 53$ and the vitamin D3 receptor. Nucleic Acids Res 34, 543-554 (2006)

111. E. de Stanchina, E. Querido, M. Narita, R.V. Davuluri, P.P. Pandolfi, G. Ferbeyre, S.W. Lowe: PML is a direct p53 target that modulates p53 effector functions. Mol Cell $13,523-535$ (2004)

112. Y. Kimura, T. Furuhata, T. Urano, K. Hirata, Y. Nakamura, T. Tokino: Genomic structure and chromosomal localization of GML (GPI-anchored molecule-like protein), a gene induced by p53. Genomics 41, 477-480 (1997)

113. C.C. Ng, H. Arakawa, S. Fukuda, H. Kondoh, Y. Nakamura: p53RFP, a p53-inducible RING-finger protein, regulates the stability of p21WAF1. Oncogene 22, 44494458 (2003)

114. S. Xie, H. Wu, Q. Wang, J.P. Cogswell, I. Husain, C. Conn, P. Stambrook, M. Jhanwar-Uniyal, W. Dai: Plk3 functionally links DNA damage to cell cycle arrest and apoptosis at least in part via the p53 pathway. $J$ Biol Chem 276, 43305-43312 (2001)

115. M. Tan, C.W. Heizmann, K. Guan, B.W. Schafer, Y. Sun: Transcriptional activation of the human S100A2 promoter by wild-type p53. FEBS Lett 445, 265-268 (1999)

116. H. Hermeking, C. Lengauer, K. Polyak, T.C. He, L. Zhang, S. Thiagalingam, K.W. Kinzler, B. Vogelstein: 143-3 sigma is a p53-regulated inhibitor of G2/M progression. Mol Cell 1, 3-11 (1997)

117. C. Duriez, N. Falette, C. Audoynaud, C. Moyret-Lalle, K. Bensaad, S. Courtois, Q. Wang, T. Soussi, A. Puisieux: The human BTG2/TIS21/PC3 gene: genomic structure, transcriptional regulation and evaluation as a candidate tumor suppressor gene. Gene 282, 207-214 (2002)

118. L.W. Ellisen, K.D. Ramsayer, C.M. Johannessen, A. Yang, H. Beppu, K. Minda, J.D. Oliner, F. McKeon, D.A. Haber: REDD1, a developmentally regulated transcriptional target of p63 and p53, links p63 to regulation of reactive oxygen species. Mol Cell 10, 9951005 (2002)
119. T.G. Hofmann, A. Möller, H. Sirma, H. Zentgraf, Y. Taya, W. Dröge, H. Will, M.L. Schmitz: Regulation of p53 activity by its interaction with homeodomain-interacting protein kinase-2. Nat Cell Biol 4, 1-10 (2002)

120. G. D'Orazi, B. Cecchinelli, T. Bruno, I. Manni, Y. Higashimoto, S. Saito, M. Gostissa, S. Coen, A. Marchetti, G. Del Sal, G. Piaggio, M. Fanciulli, E. Appella, S. Soddu: Homeodomain-interacting protein kinase-2 phosphorylates p53 at Ser 46 and mediates apoptosis. Nat Cell Biol 4, 1119 (2002)

121. N. Taira, K. Nihira, T. Yamaguchi, Y. Miki, K. Yoshida: DYRK2 is targeted to the nucleus and controls p53 via Ser46 phosphorylation in the apoptotic response to DNA damage. Mol Cell 25, 725-738 (2007)

122. K. Oda, H. Arakawa, T. Tanaka, K. Matsuda, C. Tanikawa, T. Mori, H. Nishimori, K. Tamai, T. Tokino, Y. Nakamura, Y. Taya: p53AIP1, a potential mediator of p53dependent apoptosis, and its regulation by Ser-46phosphorylated p53. Cell 102, 849-862 (2000)

123. A.M. Karst, D.L. Dai, M. Martinka, G. Li: PUMA expression is significantly reduced in human cutaneous melanomas. Oncogene 241111-241116 (2005)

124. S.J. Ichwan, S. Yamada, P. Sumrejkanchanakij, E. Ibrahim-Auerkari, K. Eto, M.A. Ikeda: Defect in serine 46 phosphorylation of p53 contributes to acquisition of p53 resistance in oral squamous cell carcinoma cells. Oncogene 25, 1216-1224 (2006)

125. L.D. Mayo, Y.R. Seo, M.W. Jackson, M.L. Smith, J. Rivera Guzman, C.K. Korgaonkar, D.B. Donner: Phosphorylation of human p53 at serine 46 determines promoter selection and whether apoptosis is attenuated or amplified. J Biol Chem 280, 25953-25959 (2005)

126. S.M. Sykes, H.S. Mellert, M.A. Holbert, K. Li, R. Marmorstein, W.S. Lane, S.B. McMahon: Acetylation of the p53 DNA-binding domain regulates apoptosis induction. Mol Cell 24, 841-851 (2006)

127. Y. Tang, J. Luo, W. Zhang, W. Gu: Tip60-dependent acetylation of p53 modulates the decision between cellcycle arrest and apoptosis. Mol Cell 24, 827-839 (2006)

128. S. Di Giovanni, C.D. Knights, M. Rao, A. Yakovlev, J. Beers, J. Catania, M.L. Avantaggiati, A. I. Faden: The tumor suppressor protein p53 is required for neurite outgrowth and axon regeneration. EMBO J 25, 4084-4096 (2006)

129. W.S. El-Deiry, S.E. Kern, J.A. Pietenpol, K.W. Kinzler, B. Vogelstein: Definition of a consensus binding site for p53. Nat Genet 1, 45-49 (1992)

130. J.C. Bourdon, V. Deguin-Chambon, J.C. Lelong, P. Dessen, P. May, B. Debuire, E. May: Further characterisation of the $\mathrm{p} 53$ responsive elementidentification 
of newcandidate genes for trans-activation by $\mathrm{p} 53$. Oncogene 14, 85-94 (1997)

131. N. Makoto, K.Yoko,M. Hitoshi, I.Kyoji: Direct interaction of $\mathrm{p} 21$ cyclindependent kinase inhibitor with the retinoblastoma tumor suppressor protein. Biochem Biophys Res Commun 263, 35- 40 (1999)

132. Y.T. Kim, M. Zhao: Aberrant cell cycle regulation in cervical carcinoma. Yonsei Med J 46, 597-613 (2005)

133. P. Nurse: Universal control mechanism regulating onset of M-phase. Nature 344, 503-508 (1990)

134. X.W. Wang, Q. Zhan, J.D. Coursen, M.A. Khan, H.U. Kontny, L. Yu, M.C. Hollander, P.M. O'Connor, A.J. Fornace Jr, C.C. Harris: GADD45 induction of a G2/M cell cycle checkpoint. Proc Natl Acad Sci U S A 96, 3706-11 (1999)

135. W.R. Taylor, G.R. Stark: Regulation of the G2/M transition by p53. Oncogene 20, 1803-15 (2001)

136. M. Hollstein, D. Sidransky, B. Vogelstein, C.C. Harris: p53 mutations in human cancers. Science 253, 49$53(1991)$

137. C. deFromentel, T. Soussi: TP53 tumor suppressor gene: a model for investigating human mutagenesis. Genes Chromosomes Cancer 4, 1- 15 (1992)

138. A.J. Levine, J. Momand, C.A. Finlay: The p53 tumour suppressor gene. Nature 351, 453-456 (1991)

139. S. Saito, H. Yamaguchi, Y. Higashimoto, C. Chao, Y. $\mathrm{Xu}$, A.J. Fornace Jr, E. Appella, C.W. Anderson: Phosphorylation site interdependence of human p53 posttranslational modifications in response to stress. $J$ Biol Chem 278, 37536-37544 (2003)

140. H. Vaziri, M.D. West, R.C. Allsopp, T.S. Davison, Y.S. Wu, C.H. Arrowsmith, G.G. Poirier, S, Benchimol: ATM-dependent telomere loss in aging human diploid fibroblasts and DNA damage lead to the posttranslational activation of p53 protein involving poly(ADP-ribose) polymerase. EMBO J 16, 6018-6033 (1997)

141. X. Wang, K. Ohnishi, A. Takahashi, T, Ohnishi: Poly(ADPribosylation) is required for p53-dependent signal transduction induced by radiation. Oncogene 17, 2819-2825 (1998)

142. G. Bakalkin, T. Yakovleva, G. Selivanova, K.P. Magnusson, L. Szekely, E. Kiseleva, G. Klein, L. Terenius, K.G. Wiman: P53 binds single stranded DNA ends and catalyzes DNA renaturation and strand transfer. Proc Natl Acad Sci USA 91, 413-417 (1994)

143. J. Jayaraman, C. Prives: Activation of p53 sequencespecific DNA binding by short single strands of DNA requires the p53 C-terminus. Cell 81, 1021-1029 (1995)
144. S. Lee, B. Elenbaas, A. Levine, J. Griffith: p53 and its $14 \mathrm{kDa}$ C-terminal domain recognize primary DNA damage in the form of insertion/ deletion mismatches. Cell 81, 1013-1020 (1995)

145. M. Reed, B. Woelker, P. Wang, Y. Wang, M.E. Anderson, P, Tegtmeyer: The C-terminal domain of p53 recognizes DNA damaged by ionizing radiation. Proc Natl Acad Sci USA 92, 9455-9459 (1995)

146. P. Oberosler, P. Hloch, U. Ramsperger, H. Stahl: p53catalyzed annealing of complementary single-stranded nucleic acids. EMBO J 12, 2389-2396 (1993)

147. D. Jean, D. Gendron, L. Delbecchi, P. Bourgaux: p53mediated DNA renaturation can mimic strand exchange. Nucleic Acids Res 25, 4004- 4012 (1997)

148. S. Lee, L. Cavallo, J. Griffith: Human p53 binds Holliday junctions strongly and facilitates their cleavage. $J$ Biol Chem 272, 7532-7539 (1997)

149. C. Dudenho"ffer, M. Kurth, F. Janus, W. Deppert, L. Wiesmu"ller: Dissociation of the recombination control and the sequence-specific transactivation function of p53. Mol Cell Biol 18, 5332-5342 (1998)

150. C. Janz, S, Su"sse, L, Wiesmu"ller: p53 and recombination intermediates: role of tetramerization at DNA junctions in complex formation and exonucleolytic degradation. Oncogene 21, 2130-2140 (2002)

151. M. Bakhanashvili: Exonucleolytic proofreading by p53 protein. Eur J Biochem 268, 2047-2054 (2001)

152. N. Albrechtsen, I. Dornreiter, F. Grosse, E. Kim, L. Wiesmuller, W. Deppert: Maintenance of genomic integrity by p53: complementary roles for activated and non-activated p53. Oncogene 18, 7706-7717 (1999)

153. P. Bertrand, Y. Saintigny, B.S. Lopez: p53's double life: transactivationindependent repression of homologous recombination. Trends Genet 20, 235-243 (2004)

154. S. Sengupta, C.C. Harris: p53: traffic cop at the crossroads of DNA repair and recombination. Nat Rev Mol Cell Biol 6, 44-55 (2005)

155. J.S. Fridman, S.W. Lowe: Control of apoptosis by p53. Oncogene 22, 9030-9040 (2003)

156. M. Selvakumaran, H.K. Lin, T. Miyashita, H.G. Wang, S. Krajewski, J.C. Reed, B. Hoffman, D. Liebermann: Immediate early up-regulation of bax expression by $\mathrm{p} 53$ but not TGFb1: A paradigm for distinct apoptotic pathways. Oncogene 9, 1791-1798 (1994)

157. T. Miyashita, S. Krajewski, M. Krajewski, H.G. Wang, H.K. Lin, D.A. Liebermann, B. Hoffman, J.C. Reed: Tumor suppressor $\mathrm{p} 53$ is a regulator of bcl-2 and bax gene expression in vitro and in vivo. Oncogene 9, 1799-1805 (1994) 
158. D.B. Vesely, B. Hoffman, D. A. Liebermann: Phosphatidylinositol 3-kinase/Akt signaling mediates interleukin-6protection against p53-induced apoptosis in M1 myeloid leukemic cells. Oncogene 13, 1-10 (2006)

159. M. Bennett, K. Macdonald, S.W. Chan, J.P. Luzio, R. Simari, P. Weissberg: Cell surface trafficking of Fas: Arapid mechanism of p53-mediated apoptosis. Science 282, 290-293 (1998)

160. L. Buckbinder, R. Talbott, S. Velascomiguel, I. Takenaka, B. Faha, B.R. Seizinger, N. Kley: Induction of the growth inhibitor IGF-binding protein 3 by p53. Nature 377, 646-649 (1995)

161. R. Baserga: Oncogenes and the strategy of growth factors. Cell 79, 927- 930 (1994)

162. K. Polyak, Y. Xia, J.L. Zweier, K.W. Kinzler, B.A. Vogelstein: Model for p53-induced apoptosis. Nature 389, 300-305 (1997)

163. R. Faraonio, P. Vergara, D. Di Marzo, M.G. Pierantoni, M. Napolitano, T. Russo, F. Cimino: p53 suppresses the Nrf2-dependent transcription of antioxidant response genes. J Biol Chem 31, 31-37 (2006)

164. U.M. Moll, N. Marchenko, X.K. Zhang: p53 and Nur77/TR3 - Transcription factors that directly target mitochondria for cell death induction. Oncogene 25, 47254743 (2006)

165. T. Shibue, S. Suzuki1, H. Okamoto, H. Yoshida, Y. Ohba, A. Takaoka, T. Taniguchi: Differential contribution of Puma and Noxa in dualregulation of p53-mediated apoptotic pathways. EMBO J 25, 4952-4962 (2006)

166. C. Caelles, A. Helmberg, M. Karin: p53-dependent apoptosis in the absence of transcriptional activation of p53-target genes. Nature 370, 220-223 (1994)

167. N.D. Marchenko, A. Zaika, U.M. Moll: Death signalinduced localization of $\mathrm{p} 53$ protein to mitochondria. A potential role in apoptotic signaling. $J$ Biol Chem 275, 16202-16212 (2000)

168. P. Dumont, J.I. Leu, A,C, Della Pietra, D.L. George, M. Murphy: The codon 72 polymorphic variants of p53 have markedly different apoptotic potential. Nat Genet 33, 357-365 (2003)

169. G.J. Griffiths, L. Dubrez, C.P. Morgan, N.A. Jones, J. Whitehouse, B.M. Corfe, C. Dive, J.A. Hickman: Cell damage-induced conformational changes of the proapoptotic protein Bak in vivo precede the onset of apoptosis. J Cell Biol 144, 903-914 (1999)

170. M. Mihara, S. Erster, A. Zaika, O. Petrenko, T. Chittenden, P. Pancoska, U.M. Moll: p53 has a direct apoptogenic role at the mitochondria. Mol Cell 11, 577-590 (2003)
171. J.E. Chipuk, T. Kuwana, L. Bouchier-Hayes, N.M. Droin, D.D. Newmeyer, M. Schuler, D.R. Green: Direct activation of $\mathrm{Bax}$ by $\mathrm{p} 53$ mediates mitochondrial membrane permeabilization and apoptosis. Science 303, 1010-1014 (2004)

172. G. Matlashewski, P. Lamb, D. Pim, J. Peacock, L. Crawford, S. Benchimol: Isolation and characterization of a human p53 cDNA clone: expression of the human p53 gene. EMBO J 3, 3257-3262 (1984)

173. D. Wolf, Z. Laver-Rudich, V. Rotter: In vitro expression of human p53 cDNA clones and characterization of the cloned human p53 gene. Mol Cell Biol 5, 1887-1893 (1985)

174. E. Harlow, N.M. Williamson, R. Ralston, D.M. Helfman, T.E. Adams: Molecular cloning and in vitro expression of a cDNA clone for human cellular tumor antigen p53. Mol Cell Biol 5, 1601-1610 (1985)

175. G. Matlashewski, D. Pim, L. Banks, L. Crawford: Alternative splicing of human p53 transcripts. Oncogene Res 1, 77-85 (1987)

176. V.L. Buchman, P.M. Chumakov, N.N. Ninkina, O.P. Samarina, G.P. Georgiev: A variation in the structure of the protein-coding region of the human p53 gene. Gene 70 , 245-252 (1988)

177. S. Ara, P.S. Lee, M.F. Hansen, H. Saya: Codon 72 polymorphism of the TP53 gene. Nucleic Acids Res 18, 4961 (1990)

178. G. Beckman, R. Birgander, A. Själander, N. Saha, P.A. Holmberg, A. Kivelä, L. Beckman: Is p53 polymorphism maintained by natural selection?. Hum Hered 44, 266-270 (1994)

179. L.A. Brooks, J.A. Tidy, B. Gusterson, L. Hiller, J. O'Nions, M. Gasco, M.C. Marin, P.J. Farrell, W.G. Kaelin Jr, T. Crook: Preferential retention of codon 72 arginine p53 in squamous cell carcinomas of the vulva occurs in cancers positive and negative for human papillomavirus. Cancer Res 60, 6875-7 (2000)

180. M.C. Marin, C.A. Jost, L.A. Brooks, M.S. Irwin, J. O'Nions, J.A. Tidy, N. James, J.M. McGregor, C.A. Harwood, I.G. Yulug, K.H. Vousden, M.J. Allday, B. Gusterson, S. Ikawa, P.W. Hinds, T. Crook, W.G. Kaelin Jr: A common polymorphism acts as an intragenic modifier of mutant p53 behaviour. Nat Genet 25, 47-54 (2000)

181. M. Bonafè, S. Salvioli, C. Barbi, M. Mishto, C. Trapassi, C. Gemelli, G. Storci, F. Olivieri, D. Monti, C. Franceschi : p53 codon 72 genotype affects apoptosis by cytosine arabinoside in blood leukocytes. Biochem Biophys Res Commun 299, 539-541 (2002)

182. A. Själander, R. Birgander, G. Hallmans, S. Cajander, P. Lenner, L. Athlin, G. Beckman, L. Beckman: p53 
polymorphisms and haplotypes in breast cancer. Carcinogenesis 17, 1313-1316 (1996)

183. X. Wu, H. Zhao, C.I. Amos, S. Shete, N. Makan, W.K. Hong, F.F. Kadlubar, M.R. Spitz: p53 Genotypes and Haplotypes Associated With Lung Cancer Susceptibility and Ethnicity. J Natl Cancer Inst 94, 681-690 (2002)

184. F. Granja, J. Morari, E.C. Morari, L.A. Correa, L.V. Assumpção, L.S. Ward: Proline homozygosity in codon 72 of p53 is a factor of susceptibility for thyroid cancer. Cancer Lett 210, 151-157 (2004)

185. A. Weston, H.M. Ling-Cawley, N.E. Caporaso, E.D. Bowman, R.N. Hoover, B.F. Trump, C.C. Harris: Determination of the allelic frequencies of an L-myc and a p53 polymorphism in human lung cancer. Carcinogenesis 15, 583-587 (1994)

186. R. Birgander, A. Själander, A. Rannug, A.K. Alexandrie, M.I. Sundberg, J. Seidegård, G. Tornling, G. Beckman, L. Beckman: p53 polymorphisms and haplotypes in lung cancer. Carcinogenesis 16, 2233-2236 (1995)

187. A.N. Rosenthal, A. Ryan, R.M. Al-Jehani, A. Storey, C.A .Harwood, I.J. Jacobs: p53 codon 72 polymorphism and risk of cervical cancer in UK. Lancet 352, 871-872 (1998)

188. E. Felley-Bosco, A. Weston, H.M. Cawley, W.P. Bennett, C.C. Harris: Functional studies of a germ-line polymorphism at codon 47 within the p53 gene. Am J Hum Genet 53, 752-759 (1993)

189. X. Li, P. Dumont, A. Della Pietra, C. Shetler, M.E. Murphy: The codon 47 polymorphism in p53 is functionally significant. $J$ Biol Chem 280, 24245-2425 (2005)

190. F. Aguilar, C.C. Harris, T. Sun, M. Hollstein, P. Cerutti: Geographic variation of p53 mutational profile in nonmalignant human liver. Science 264, 1317-1319 (1994)

191. D. Lin, M. Fiscella, P.M. O'Connor, J. Jackman, M. Chen, L.L. Luo, A. Sala, S. Travali, E. Appella, W.E. Mercer: Constitutive expression of B-myb can bypass p53induced Waf1/Cip1-mediated G1 arrest. Proc Natl Acad Sci US A 91, 10079-10083 (1994)

192. G.M. Clore, J.G. Omichinski, K. Sakaguchi, N. Zambrano, H. Sakamoto, E. Appella, A. M. Gronenborn: High-resolution structure of the oligomerization domain of p53 by multidimensional NMR. Science 265, 386-391 (1994)

193. P.D. Jeffrey, S. Gorina, N.P. Pavletich: Crystal structure of the tetramerization domain of the p53 tumor suppressor at 1.7 angstroms. Science 267, 1498-1502 (1995)

194. T.R. Hupp, D.P. Lane: Allosteric activation of latent p53 tetramers. Curr Biol 4, 865-875 (1994)
195. N. Horikoshi, A. Usheva, J. Chen, A.J. Levine, R. Weinmann, T. Shenk: Two domains of p53 interact with the TATA-binding protein, and the adenovirus 13S E1A protein disrupts the association, relieving p53- ediated transcriptional repression. Mol Cell Biol 15, 227- 234 (1995)

196. W. Wang, H. Johansson, T. Kvasnicka, L.O. Farnebo, L. Grimelius: Detection of apoptotic cells and expression of Ki-67 antigen, Bcl-2, p53 oncoproteins in human parathyroid adenoma. APMIS 104, 789-796 (1996)

197. S. Collot-Teixeira, J. Bass, F. Denis, S. Ranger-Rogez: Human tumor suppressor p53 and DNA viruses. Rev Med Virol 14, 301-319 (2004)

198. R. Mahieux, C.A. Pise-Masison, C. Nicot, P. Green, W.W. Hall, J.N. Brady: Inactivation of $\mathrm{p} 53$ by HTLV type 1 and HTLV type 2 Tax trans-activators. AIDS Res Hum Retroviruses 16, 1677-1681 (2000)

199. P. Sabbatini, S.K. Chiou, L. Rao, E. White: Modulation of p53-mediated transcriptional repression and apoptosis by the adenovirus E1B 19K protein. Mol Cell Biol 15, 1060-1070 (1995)

200. D. Jiang, A. Srinivasan, G. Lozano, P.D. Robbins: SV40 T antigen abrogates p53-mediated transcriptional activity. Oncogene 8, 2805-2812 (1993)

201. J.A. Mietz, T. Unger, J.M. Huibregtse, P.M. Howley: The transcriptional transactivation function of wild-type p53 is inhibited by SV40 large T-antigen and by HPV-16 E6 oncoprotein. EMBO J 11, 5013-5020 (1992)

202. D.P. Lane, L.V. Crawford: T antigen is bound to a host protein in SV40-transformed cells. Nature 278, 261263 (1979)

203. D.I. Linzer, W. Maltzman, A.J. Levine: The SV40 A gene product is required for the production of a 54,000 MW cellular tumor antigen. Virology 98, 308-318 (1979)

204. J.N. Harada, A.J. Berk: p53-Independent and dependent requirements for E1B-55K in adenovirus type 5 replication. J Virol 73, 5333-5344 (1999)

205. E. Querido, J.G. Teodoro, P.E. Branton: Accumulation of $\mathrm{p} 53$ induced by the adenovirus E1A protein requires regions involved in the stimulation of DNA synthesis. $J$ Virol 71, 3526-3533 (1997)

206. J.M. Huibregtse, M. Scheffner, P.M. Howley: A cellular protein mediates association of p53 with the E6 oncoprotein of human papillomavirus types 16 or 18 . EMBO J 10, 4129-4135 (1991)

207. M. Scheffner, T. Takahashi, J.M. Huibregtse, J.D. Minna, P.M. Howley: Interaction of the human papillomavirus type 16 E6 oncoprotein with wild-type and mutant human p53 proteins. J Virol 66, 5100-5105 (1992) 
208. I. Malanchi, R. Accardi, F. Diehl, A. Smet, E. Androphy, J. Hoheisel, M. Tommasino: Human papillomavirus type 16 E6 promotes retinoblastoma protein phosphorylation and cell cycle progression. $J$ Virol 78, 13769-71378 (2004)

209. H. Lichtig, M. Algrisi, L.E. Botzer, T. Abadi, Y. Verbitzky, A. Jackman, M. Tommasino, I. Zehbe, L. Sherman: HPV16 E6 natural variants exhibit different activities in functional assays relevant to the carcinogenic potential of E6. Virology 350, 216-227 (2006)

210. Y. Asadurian, H. Kurilin, H. Lichtig, A. Jackman, P. Gonen, M. Tommasino, I. Zehbe, L. Sherman: Activities of human papillomavirus 16 E6 natural variants in human keratinocytes. J Med Virol 79, 1751-1760 (2007)

211. G. Ferbeyre, E. de Stanchina, E. Querido, N. Baptiste, C. Prives, S.W. Lowe: PML is induced by oncogenic ras and promotes premature senescence. Genes Dev 14, 20152027 (2000)

212. W.Q. Jiang, L. Szekely, G. Klein, N. Ringertz: Intranuclear redistribution of SV40T, p53, and PML in a conditionally SV40T-immortalized cell line. Exp Cell Res 229, 289-300 (1996)

213. G.G. Maul, D. Negorev, P. Bell, A.M. Ishov: Review: properties and assembly mechanisms of ND10, PML bodies, or PODs. J Struct Biol 129, 278-287 (2000)

214. M. Nevels, T. Spruss, H. Wolf, T. Dobner: The adenovirus E4orf6 protein contributes to malignant transformation by antagonizing E1A-induced accumulation of the tumor suppressor protein p53. Oncogene 18, 9-17 (1999)

215. B. Terris, V. Baldin, S. Dubois, C. Degott, J.F. Flejou, D. Hénin, A. Dejean: PML nuclear bodies are general targets for inflammation and cell proliferation. Cancer Res $55,1590-1597$ (1995)

216. R.D. Everett, G.G. Maul: HSV-1 IE protein Vmw110 causes redistribution of PML. EMBO $J$ 13, 5062-5069 (1994)

217. S.M. Dilworth: Cell alterations induced by the large Tantigens of SV40 and polyoma virus. Semin Cancer Biol 1, 407-414 (1990)

218. O. Mor, M. Read, M. Fried: p53 in polyoma virus transformed REF52 cells. Oncogene 15, 3113-3119 (1997)

219. M.G. Moule, C.H. Collins, F. McCormick, M. Fried: Role for PP2A in ARF signaling to p53. Proc Natl Acad Sci US A 101, 14063-14066 (2004)

220. A. Yang, F. McKeon: P63 and P73: P53 mimics, menaces and more. Nat Rev Mol Cell Biol 1, 199-207 (2000)
221. G. Melino, X. Lu, M. Gasco, T. Crook, R.A. Knight: Functional regulation of $\mathrm{p} 73$ and p63: development and cancer. Trends Biochem. Sci 28, 663-670 (2003)

222. U.M. Moll, N. Slade: p63 and p73: roles in development and tumor formation. Mol Cancer Res 2, 371386 (2004)

223. E.R. Flores, K.Y. Tsai, D. Crowley, S. Sengupta, A. Yang, F. McKeon, T. Jacks: p63 and p73 are required for p53-dependent apoptosis in response to DNA damage. Nature 416, 560-564 (2002)

224. T. Stiewe, S. Zimmermann, A. Frilling, Esche H, B.M. Pützer: Transactivation deficient DeltaTA-p73 acts as an oncogene. Cancer Res 62, 3598-3602 (2002)

225. J.Y. Yang, W. Xia, M.C. Hu: Ionizing radiation activates expression of FOXO3a, Fas ligand, and Bim, and induces cell apoptosis. Int J Oncol 29, 643-648 (2006)

226. W.M. Chan, W.Y. Siu, A. Lau, R.Y. Poon: How many mutant p53 molecules are needed to inactivate a tetramer?. Mol Cell Biol 24, 3536-3551 (2004)

227. M.P. DeYoung, C.M. Johannessen, C.O. Leong, W. Faquin, J.W. Rocco, L.W. Ellisen: Tumor- specific p73 upregulation mediates p63 dependence in squamous cell carcinoma. Cancer Res 66, 9362-9368 (2006)

228. J.W. Rocco, C.O. Leong, N. Kuperwasser, M.P. DeYoung, L.W. Ellisen: p63 mediates survival in squamous cell carcinoma by suppression of $\mathrm{p} 73$ - dependent apoptosis. Cancer Cell 9, 45-56 (2006)

229. T.S. Davison, C. Vagner, M. Kaghad, A. Ayed, D. Caput, C.H. Arrowsmith: p73 and p63 are homotetramers capable of weak heterotypic interactions with each other but not with p53. J Biol Chem 274, 18709-18714 (1999)

230. T. Stiewe, C.C. Theseling, B.M. Pützer: Transactivation-deficient Delta TA-p73 inhibits p53 by direct competition for DNA binding: implications for tumorigenesis. J Biol Chem 277, 14177-14185 (2002)

Key Words: Cancer, p53, Cell Signaling, Apoptosis, Cell Cycle, Review

Send correspondence to: Amalia Azzariti, Clinical Experimental Oncology Laboratory, National Cancer Institute, Via Hahnemann, 10, 70126 Bari , Italy, Tel: 39-080-5555556, Fax: 39-080-5555561, E-mail: a.azzariti@oncologico.bari.it

http://www.bioscience.org/current/vol15.htm 